Supplement of Hydrol. Earth Syst. Sci., 25, 3855-3874, 2021

https://doi.org/10.5194/hess-25-3855-2021-supplement

(c) Author(s) 2021. CC BY 4.0 License.

(c) (i)

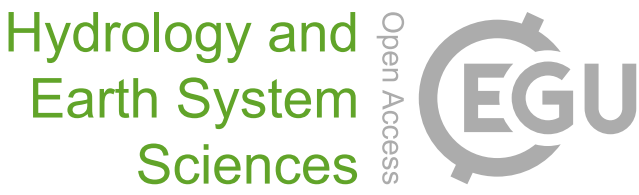

Supplement of

\title{
Robust historical evapotranspiration trends across climate regimes
}

Sanaa Hobeichi et al.

Correspondence to: Sanaa Hobeichi (s.hobeichi@unsw.edu.au)

The copyright of individual parts of the supplement might differ from the article licence. 


\section{Supplementary Material}

S1. Flux tower data

4 Table S1: Observational data used to constrained the weighting and/or validate DOLCE V2. Site data was

5 accessed during July - November, 2019. Data source includes Ameriflux (ameriflux.Ibl.gov), the

6 Atmospheric Radiation Measurement (ARM; arm.gov), AsiaFlux (asiaflux.net), European Fluxes Database

7 (europe-fluxdata.eu), Fluxnet 2015, LaThuile Free Fair Use (fluxnet.fluxdata.org), Oak Ridge data

8 repository (daac.ornl.gov), OzFlux (ozflux.org.au) and individual site principal investigators (PI).

\begin{tabular}{|c|c|c|c|c|c|}
\hline Site ID & Country & Longitude & Latitude & Data source & Reference \\
\hline AR-SLu & Argentina & -66.4598 & -33.4648 & Fluxnet 2015 & (Cleverly et al., 2013) \\
\hline AT-Neu & Austria & 11.3175 & 47.11667 & Fluxnet 2015 & (Cleverly et al., 2013) \\
\hline AU-Ade & Australia & 131.1178 & -13.0769 & Fluxnet 2015 & (Beringer, 2013a) \\
\hline AU-ASM & Australia & 133.249 & -22.283 & Fluxnet 2015 & (Cleverly et al., 2013) \\
\hline AU-Cum & Australia & 150.7225 & -33.6133 & Fluxnet 2015 & (Pendall, 2015) \\
\hline $\mathrm{AU}-\mathrm{CPr}$ & Australia & 140.5891 & -34.0021 & OzFlux & (Calperum Tech, 2013) \\
\hline $\mathrm{AU}-\mathrm{CTr}$ & Australia & 145.4469 & -16.1032 & OzFlux & (Liddell, 2013a ) \\
\hline AU-DaS & Australia & 131.388 & -14.1593 & Fluxnet 2015 & (Isaac, 2010) \\
\hline AU-Dry & Australia & 132.3706 & -15.2588 & Fluxnet 2015 & (Beringer, 2013b) \\
\hline $\mathrm{AU}-\mathrm{Emr}$ & Australia & 148.4746 & -23.8587 & Fluxnet 2015 & (Schroder, 2014) \\
\hline AU-Fog & Australia & 131.3072 & -12.5452 & Fluxnet 2015 & (Beringer, 2013c) \\
\hline AU-How & Australia & 131.1523 & -12.4943 & OzFlux & (Andrykanus, 2012) \\
\hline AU-Gin & Australia & 115.65 & -31.375 & Fluxnet 2015 & (Silberstein, 2015) \\
\hline $\begin{array}{l}\mathrm{AU}- \\
\text { GWW }\end{array}$ & Australia & 120.6542 & -30.1914 & OzFlux & (Macfarlane, 2013) \\
\hline AU-Lox & Australia & 140.6551 & -34.4704 & Fluxnet 2015 & (Ewenz, 2015) \\
\hline AU-RDF & Australia & 132.4776 & -14.5636 & Fluxnet 2015 & (Beringer, 2014a) \\
\hline AU-Rig & Australia & 145.576 & -36.656 & Fluxnet 2015 & (Beringer, 2014a) \\
\hline AU-Rob & Australia & 145.6302 & -17.1174 & Fluxnet 2015 & (Liddell, 2013b) \\
\hline AU-Stp & Australia & 133.3503 & -17.1508 & Fluxnet 2015 & (Beringer, 2013d) \\
\hline AU-TTE & Australia & 133.64 & -22.287 & Fluxnet 2015 & (Cleverly, 2013) \\
\hline AU-Tum & Australia & 148.1516 & -35.6566 & Fluxnet 2015 & (Woodgate, 2013) \\
\hline AU-Ync & Australia & 146.2907 & -34.9893 & OzFlux & (Beringer, 2013e) \\
\hline AU-Wac & Australia & 145.1873 & -37.429 & Fluxnet 2015 & (Beringer, 2013f) \\
\hline AU-Whr & Australia & 145.0294 & -36.6732 & OzFlux & (Beringer, 2017) \\
\hline $\begin{array}{l}\text { AU- } \\
\text { Wom }\end{array}$ & Australia & 144.0944 & -37.4222 & Fluxnet 2015 & (Stefan, 2013) \\
\hline BE-Bra & Belgium & 4.52056 & 51.30917 & Fluxnet 2015 & (Stoy et al., 2013) \\
\hline BE-Lon & Belgium & 4.74613 & 50.55159 & Fluxnet 2015 & (McCaughey et al., 2006) \\
\hline BE-Vie & Belgium & 5.99805 & 50.30507 & Fluxnet 2015 & (Stoy et al., 2013) \\
\hline BNS & China & 101.2653 & 21.9275 & AsiaFlux & asiaflux.net \\
\hline
\end{tabular}




\begin{tabular}{|c|c|c|c|c|c|}
\hline BR-Ban & Brazil & -50.1591 & -9.82442 & Oak Ridge & (Saleska et al., 2013) \\
\hline BR-Ji1 & Brazil & -62.3572 & -10.7618 & Oak Ridge & (Saleska et al., 2013) \\
\hline BR-Ji3 & Brazil & -61.9331 & -10.078 & Oak Ridge & (Saleska et al., 2013) \\
\hline BR-Ma2 & Brazil & -60.2091 & -2.609 & Oak Ridge & (Saleska et al., 2013) \\
\hline BR-Sa1 & Brazil & -54.959 & -2.857 & Oak Ridge & (Saleska et al., 2013) \\
\hline BR-Sa3 & Brazil & -54.9714 & -3.01803 & LaThuile & (Stoy et al., 2013) \\
\hline BW-Ma1 & Botswana & 23.56033 & -19.9165 & LaThuile & (Stoy et al., 2013) \\
\hline CA-ARF & Canada & -83.955 & 52.7008 & AmeriFlux & (Euskirchen et al., 2017) \\
\hline CA-Ca2 & Canada & -125.291 & 49.8705 & AmeriFlux & (Chen et al., 2006) \\
\hline CA-Cbo & Canada & -79.9333 & 44.3167 & AmeriFlux & (Barr et al., 2002) \\
\hline CA-Ca3 & Canada & -124.9 & 49.5346 & AmeriFlux & (Chen et al., 2006) \\
\hline CA-Let & Canada & -112.94 & 49.7093 & AmeriFlux & (Conte et al., 2003) \\
\hline CA-Man & Canada & -98.4808 & 55.8796 & LaThuile & fluxnet.ornl.gov \\
\hline CA-Mer & Canada & -75.5186 & 45.4094 & LaThuile & (Lafleur, et al., 2003) \\
\hline CA-NS2 & Canada & -98.5247 & 55.9058 & LaThuile & fluxnet.ornl.gov \\
\hline CA-NS6 & Canada & -98.9644 & 55.9167 & LaThuile & fluxnet.ornl.gov \\
\hline CA-NS7 & Canada & -99.9483 & 56.6358 & LaThuile & fluxnet.ornl.gov \\
\hline CA-Ojp & Canada & -104.692 & 53.9163 & AmeriFlux & (Baldocchi et al., 2000) \\
\hline CA-Qcu & Canada & -74.0365 & 49.2671 & LaThuile & (Chu et al., 2018) \\
\hline CA-Qfo & Canada & -74.3421 & 49.6925 & Fluxnet 2015 & fluxnet.ornl.gov \\
\hline CA-SCC & Canada & -121.299 & 61.3079 & AmeriFlux & (Euskirchen et al., 2017) \\
\hline CA-SF1 & Canada & -105.818 & 54.485 & Fluxnet 2015 & fluxnet.ornl.gov \\
\hline CA-SF3 & Canada & -106.005 & 54.0916 & Fluxnet 2015 & fluxnet.ornl.gov \\
\hline CA-TP1 & Canada & -80.5595 & 42.6609 & AmeriFlux & (Arain et al., 2005) \\
\hline CA-TP4 & Canada & -80.3574 & 42.7102 & AmeriFlux & (Arain et al., 2005) \\
\hline $\mathrm{CH}-\mathrm{Cha}$ & Switzerland & 8.41044 & 47.21022 & Fluxnet 2015 & fluxnet.ornl.gov \\
\hline CH-Dav & Switzerland & 9.85592 & 46.81533 & Fluxnet 2015 & fluxnet.ornl.gov \\
\hline $\mathrm{CH}-\mathrm{Fru}$ & Switzerland & 8.53778 & 47.11583 & Fluxnet 2015 & fluxnet.ornl.gov \\
\hline CH-Oe1 & Switzerland & 7.73194 & 47.28583 & LaThuile & fluxnet.ornl.gov \\
\hline CN-Cng & China & 123.5092 & 44.5934 & Fluxnet 2015 & fluxnet.ornl.gov \\
\hline CN-Du2 & China & 116.2836 & 42.0467 & Fluxnet 2015 & (Stoy et al., 2013) \\
\hline CN-HaM & China & 101.18 & 37.37 & Fluxnet 2015 & (Li et al., 2013) \\
\hline $\mathrm{CN}-\mathrm{QHB}$ & China & 101.332 & 37.60743 & Asiaflux & asiaflux.net \\
\hline CN-QYZ & China & 115.0663 & 26.73396 & AsiaFlux & asiaflux.net \\
\hline CZ-BK1 & Czech Republic & 18.53688 & 49.50208 & $\begin{array}{l}\text { European } \\
\text { Fluxes DB }\end{array}$ & europe-fluxdata.eu \\
\hline CZ-BK2 & Czech Republic & 18.54285 & 49.49443 & $\begin{array}{l}\text { European } \\
\text { Fluxes DB }\end{array}$ & europe-fluxdata.eu \\
\hline CZ-RAJ & Czech Republic & 16.69651 & 49.44372 & $\begin{array}{l}\text { European } \\
\text { Fluxes DB }\end{array}$ & europe-fluxdata.eu \\
\hline CZ-Stn & Czech Republic & 17.9699 & 49.03598 & $\begin{array}{l}\text { European } \\
\text { Fluxes DB }\end{array}$ & europe-fluxdata.eu \\
\hline CZ-wet & Czech Republic & 14.77035 & 49.02465 & Fluxnet 2015 & (Stoy et al., 2013) \\
\hline DE-Geb & Germany & 10.9143 & 51.1001 & Fluxnet 2015 & (Revill et al., 2013) \\
\hline
\end{tabular}




\begin{tabular}{|c|c|c|c|c|c|}
\hline DE-Hai & Germany & 10.453 & 51.07917 & Fluxnet 2015 & (Ershadi et al., 2014) \\
\hline DE-Hte & Germany & 12.17611 & 54.21028 & $\begin{array}{l}\text { European } \\
\text { Fluxes DB }\end{array}$ & europe-fluxdata.eu \\
\hline $\mathrm{DE}-\mathrm{Hzd}$ & Germany & 13.48982 & 50.96403 & $\begin{array}{l}\text { European } \\
\text { Fluxes DB }\end{array}$ & europe-fluxdata.eu \\
\hline DE-Kli & Germany & 13.52251 & 50.89288 & Fluxnet 2015 & (Revill et al., 2013) \\
\hline DE-Lkb & Czech Republic & 13.30467 & 49.09962 & Fluxnet 2015 & fluxnet.ornl.gov \\
\hline DE-Meh & Germany & 10.65547 & 51.27531 & LaThuile & fluxnet.ornl.gov \\
\hline DE-RuR & Germany & 6.30413 & 50.62191 & Fluxnet 2015 & fluxnet.ornl.gov \\
\hline DE-Seh & Germany & 6.44965 & 50.87062 & Fluxnet 2015 & fluxnet.ornl.gov \\
\hline DE-SfN & Germany & 11.3275 & 47.80639 & Fluxnet 2015 & fluxnet.ornl.gov \\
\hline DE-Wet & Germany & 11.45753 & 50.4535 & LaThuile & (Stoy et al., 2013) \\
\hline DE-Zrk & Germany & 12.88901 & 53.87594 & Fluxnet 2015 & fluxnet.ornl.gov \\
\hline DK-Fou & Denmark & 9.58722 & 56.4842 & LaThuile & (Stoy et al., 2013) \\
\hline DK-Ris & Denmark & 12.09722 & 55.53028 & LaThuile & (Gilmanov et al., 2010) \\
\hline DK-Sor & Denmark & 11.64464 & 55.48587 & Fluxnet 2015 & (Stoy et al., 2013) \\
\hline DK-ZaF & Greenland & -20.5557 & 74.4791 & Fluxnet 2015 & (Soegaard and Nordstroem, 1999) \\
\hline ES-ES1 & Spain & -0.31881 & 39.34597 & LaThuile & (Stoy et al., 2013) \\
\hline ES-LgS & Spain & -2.96583 & 37.09794 & Fluxnet 2015 & fluxnet.ornl.gov \\
\hline ES-LJu & Spain & -2.75212 & 36.92659 & Fluxnet 2015 & fluxnet.ornl.gov \\
\hline ES-LMa & Spain & -5.77336 & 39.9415 & LaThuile & (Stoy et al., 2013) \\
\hline ES-VDA & Spain & 1.4485 & 42.15218 & LaThuile & (Stoy et al., 2013) \\
\hline $\mathrm{FI}-\mathrm{Hyy}$ & Finland & 24.295 & 61.8475 & Fluxnet 2015 & (Stoy et al., 2013) \\
\hline Fl-Jok & Finland & 23.51345 & 60.8986 & Fluxnet 2015 & (Reichstein et al., 2005) \\
\hline FI-Kaа & Finland & 27.29503 & 69.14069 & LaThuile & (Aurela et al., 2001) \\
\hline $\mathrm{Fl}-\mathrm{Kns}$ & Finland & 24.35617 & 60.64683 & $\begin{array}{l}\text { European } \\
\text { Fluxes DB }\end{array}$ & europe-fluxdata.eu \\
\hline FI-Lom & Finland & 24.20918 & 67.9972 & Fluxnet 2015 & fluxnet.ornl.gov \\
\hline FI-Sod & Finland & 26.63783 & 67.36186 & Fluxnet 2015 & (Stoy et al., 2013) \\
\hline FI-Var & Finland & 29.61 & 67.7549 & $\begin{array}{l}\text { European } \\
\text { Fluxes DB }\end{array}$ & europe-fluxdata.eu \\
\hline FR-Fon & France & 2.78014 & 48.4764 & LaThuile & (Stoy et al., 2013) \\
\hline FR-Gri & France & 1.95191 & 48.84422 & Fluxnet 2015 & (Loubet et al., 2011) \\
\hline FR-Hes & France & 7.06556 & 48.67416 & LaThuile & (Reichstein et al., 2005) \\
\hline $\mathrm{FR}-\mathrm{LBr}$ & France & -0.7693 & 44.71711 & Fluxnet 2015 & fluxnet.ornl.gov \\
\hline FR-Lq1 & France & 2.73583 & 45.64306 & LaThuile & (Gilmanov et al., 2007) \\
\hline FR-Lq2 & France & 2.73703 & 45.63919 & LaThuile & (Gilmanov et al., 2007) \\
\hline FR-Lus & France & 0.12065 & 46.41425 & $\begin{array}{l}\text { European } \\
\text { Fluxes DB }\end{array}$ & europe-fluxdata.eu \\
\hline FR-Pue & France & 3.59583 & 43.74139 & Fluxnet 2015 & (Wei et al., 2014) \\
\hline GRW & Portugal & -28.0297 & 39.0911 & ARM & (ARM, 2009) \\
\hline HFE & China & 116.782 & 32.5584 & ARM & (ARM, 2008) \\
\hline HFK & S.Korea & 127.57 & 34.55389 & AsiaFlux & asiaflux.net \\
\hline HU-He1 & Hungary & 16.65222 & 46.95583 & $\mathrm{PI}$ & (Barcza et al., 2009) \\
\hline HU-Bug & Hungary & 19.6013 & 46.6911 & LaThuile & (Stoy et al., 2013) \\
\hline
\end{tabular}




\begin{tabular}{|c|c|c|c|c|c|}
\hline HU-Mat & Hungary & 19.726 & 47.8469 & LaThuile & (Stoy et al., 2013) \\
\hline ID-Pag & Malaysia & 114.036 & 2.345 & LaThuile & (Hirano et al., 2007) \\
\hline IE-Ca1 & Ireland & -6.91814 & 52.85879 & LaThuile & (Stoy et al., 2013) \\
\hline IE-Dri & Ireland & -8.75181 & 51.98669 & LaThuile & (Stoy et al., 2013) \\
\hline IL-Yat & Israel & 35.0515 & 31.345 & LaThuile & (Reichstein et al., 2003) \\
\hline IS-Gun & Iceland & -20.2167 & 63.8333 & LaThuile & fluxnet.ornl.gov \\
\hline IT-BCi & Italy & 14.95744 & 40.52375 & Fluxnet 2015 & fluxnet.ornl.gov \\
\hline IT-CA3 & Italy & 12.0222 & 42.38 & Fluxnet 2015 & fluxnet.ornl.gov \\
\hline IT-Cas & Italy & 8.71752 & 45.07005 & LaThuile & fluxnet.ornl.gov \\
\hline IT-Col & Italy & 13.58814 & 41.84936 & Fluxnet 2015 & (Stoy et al., 2013) \\
\hline IT-Cpz & Italy & 12.37611 & 41.70525 & Fluxnet 2015 & (Wei et al., 2014) \\
\hline IT-Isp & Italy & 8.63358 & 45.81264 & Fluxnet 2015 & fluxnet.ornl.gov \\
\hline IT-Lav & Italy & 11.28132 & 45.9562 & Fluxnet 2015 & (Cescatti and Zorer, 2003) \\
\hline IT-Lec & Italy & 11.26975 & 43.30359 & LaThuile & (Stoy et al., 2013) \\
\hline IT-LMa & Italy & 7.58259 & 45.15258 & LaThuile & fluxnet.ornl.gov \\
\hline IT-Mal & Italy & 11.70334 & 46.11402 & LaThuile & (Gilmanov et al., 2007) \\
\hline IT-MBo & Italy & 11.04583 & 46.01468 & Fluxnet 2015 & (Gilmanov et al., 2007) \\
\hline IT-Noe & Italy & 8.15146 & 40.60613 & Fluxnet 2015 & fluxnet.ornl.gov \\
\hline IT-Non & Italy & 11.09109 & 44.69019 & LaThuile & fluxnet.ornl.gov \\
\hline IT-PT1 & Italy & 9.06104 & 45.20087 & Fluxnet 2015 & (Stoy et al., 2013) \\
\hline IT-Ren & Italy & 11.43369 & 46.58686 & Fluxnet 2015 & (Stoy et al., 2013) \\
\hline IT-Ro3 & Italy & 11.91542 & 42.37539 & $\begin{array}{l}\text { European } \\
\text { Fluxes DB }\end{array}$ & europe-fluxdata.eu \\
\hline IT-SRo & Italy & 10.28444 & 43.72786 & Fluxnet 2015 & fluxnet.ornl.gov \\
\hline IT-Tor & Italy & 7.57806 & 45.84444 & Fluxnet 2015 & (Galvagno et al., 2013) \\
\hline JP-TKY & Japan & 137.4231 & 36.14617 & AsiaFlux & (Hirata et al., 2008) \\
\hline MAO & Brazil & -60.5981 & -3.21297 & ARM & (ARM, 2014) \\
\hline MMF & Japan & 142.2613 & 44.3219 & AsiaFlux & asiaflux.net \\
\hline MN-SKT & Mongolia & 108.6543 & 48.35186 & AsiaFlux & (Hirata et al., 2008) \\
\hline MSE & Japan & 140.0269 & 36.054 & AsiaFlux & asiaflux.net \\
\hline MX-Lpa & Mexico & -110.438 & 24.1293 & AmeriFlux & (Bell et al., 2012) \\
\hline NIM & Niger & 2.1758 & 13.4773 & ARM & (ARM, 2005) \\
\hline NL-Ca1 & Netherlands & 4.927 & 51.971 & LaThuile & fluxnet.ornl.gov \\
\hline NL-Haa & Netherlands & 4.80556 & 52.00361 & LaThuile & fluxnet.ornl.gov \\
\hline NL-Hor & Netherlands & 5.0713 & 52.24035 & Fluxnet 2015 & (Sulkava et al., 2011) \\
\hline NL-Loo & Netherlands & 5.74356 & 52.16658 & Fluxnet 2015 & (Gash and Dolman, 2003) \\
\hline NL-Mol & Netherlands & 4.63908 & 51.65 & LaThuile & (Gilmanov et al., 2007) \\
\hline NO-Adv & Norway & 15.923 & 78.186 & Fluxnet 2015 & fluxnet.ornl.gov \\
\hline NSA & USA & -156.608 & 71.325 & ARM & (ARM, 2011) \\
\hline NZ-BFu & New Zealand & 171.9268 & -43.5918 & OzFlux & (Laubach, 2016) \\
\hline PL-wet & Poland & 16.3094 & 52.7622 & LaThuile & (stoy et al., 2013) \\
\hline PT-Esp & Portugal & -8.6018 & 38.6394 & LaThuile & (stoy et al., 2013) \\
\hline PT-Mi1 & Portugal & -8.00006 & 38.54064 & LaThuile & (stoy et al., 2013) \\
\hline
\end{tabular}




\begin{tabular}{|c|c|c|c|c|c|}
\hline PT-Mi2 & Portugal & -8.02455 & 38.4765 & LaThuile & (stoy et al., 2013) \\
\hline RU-Cok & Russia & 147.4943 & 70.82914 & Fluxnet 2015 & (Stoy et al., 2013) \\
\hline RU-Fyo & Russia & 32.92208 & 56.46153 & Fluxnet 2015 & (Stoy et al., 2013) \\
\hline RU-Ha1 & Russia & 90.00215 & 54.72517 & Fluxnet 2015 & (Belelli Marchesini et al., 2007) \\
\hline RU-Ha2 & Russia & 89.95664 & 54.77301 & LaThuile & (Belelli Marchesini et al., 2007) \\
\hline RU-Ha3 & Russia & 89.07785 & 54.70455 & LaThuile & (Belelli Marchesini et al., 2007) \\
\hline RU-Zot & Russia & 89.3508 & 60.8008 & LaThuile & (Eugster et al., 2000) \\
\hline SD-Dem & Sudan & 30.4783 & 13.2829 & Fluxnet 2015 & fluxnet.ornl.gov \\
\hline SE-Deg & Sweden & 19.55669 & 64.18197 & LaThuile & fluxnet.ornl.gov \\
\hline SE-Faj & Sweden & 13.55351 & 56.26547 & LaThuile & (Stoy et al., 2013) \\
\hline SE-Fla & Sweden & 19.45694 & 64.11278 & LaThuile & (Stoy et al., 2013) \\
\hline SE-Nor & Sweden & 17.4795 & 60.0865 & LaThuile & (Stoy et al., 2013) \\
\hline SE-Sk2 & Sweden & 17.84006 & 60.12967 & LaThuile & (Stoy et al., 2013) \\
\hline SE-Svb & Sweden & 19.7745 & 64.25611 & $\begin{array}{l}\text { European } \\
\text { Fluxes DB }\end{array}$ & europe-fluxdata.eu \\
\hline SGP & USA & -96.855 & 37.521 & ARM & (ARM, 1997) \\
\hline SN-Dhr & Senegal & -15.4322 & 15.40278 & Fluxnet 2015 & fluxnet.ornl.gov \\
\hline TWP & Australia & 130.881 & -12.486 & ARM & (ARM, 2013) \\
\hline UK-EBu & UK & -3.20578 & 55.866 & LaThuile & (Stoy et al., 2013) \\
\hline UK-ESa & UK & -2.85861 & 55.90694 & LaThuile & (Stoy et al., 2013) \\
\hline UK-Gri & UK & -3.79806 & 56.60722 & LaThuile & (Stoy et al., 2013) \\
\hline UK-Ham & UK & -0.8583 & 51.15353 & LaThuile & (Stoy et al., 2013) \\
\hline UK-LBT & UK & -0.1389 & 51.5215 & $\begin{array}{l}\text { European } \\
\text { Fluxes DB }\end{array}$ & europe-fluxdata.eu \\
\hline UK-PL3 & UK & -1.26667 & 51.45 & LaThuile & fluxnet.ornl.gov \\
\hline UK-Tad & UK & -2.82864 & 51.2071 & LaThuile & fluxnet.ornl.gov \\
\hline US-ADR & USA & -116.693 & 36.7653 & AmeriFlux & (Euskirchen et al., 2017) \\
\hline US-AR1 & USA & -99.42 & 36.4267 & Fluxnet 2015 & fluxnet.ornl.gov \\
\hline US-AR2 & USA & -99.5975 & 36.6358 & Fluxnet 2015 & fluxnet.ornl.gov \\
\hline US-ARc & USA & -98.0401 & 35.54649 & Fluxnet 2015 & (Stoy et al., 2013) \\
\hline US-ARM & USA & -97.4888 & 36.6058 & Fluxnet 2015 & (Bagley et al., 2017) \\
\hline US-Aud & USA & -110.51 & 31.5907 & AmeriFlux & (Baldocchi et al., 2015) \\
\hline US-Bar & USA & -71.2881 & 44.0646 & LaThuile & fluxnet.ornl.gov \\
\hline US-Bkg & USA & -96.8362 & 44.3453 & AmeriFlux & (Euskirchen et al., 2017) \\
\hline US-Blk & USA & -103.65 & 44.158 & AmeriFlux & (Euskirchen et al., 2017) \\
\hline US-Blo & USA & -120.633 & 38.8952 & Fluxnet 2015 & (Reichstein et al., 2003) \\
\hline US-Bo1 & USA & -88.2904 & 40.0062 & LaThuile & (Stoy et al., 2013) \\
\hline US-Br3 & USA & -93.6936 & 41.9747 & AmeriFlux & (Chu et al., 2018) \\
\hline US-Cop & USA & -109.39 & 38.09 & Fluxnet 2015 & fluxnet.ornl.gov \\
\hline US-CPk & USA & -106.119 & 41.068 & AmeriFlux & (Chu et al., 2018) \\
\hline US-Ctn & USA & -101.847 & 43.95 & AmeriFlux & (Euskirchen et al., 2017) \\
\hline US-CZ2 & USA & -119.257 & 37.0311 & AmeriFlux & (Euskirchen et al., 2017) \\
\hline US-Dix & USA & -74.4346 & 39.9712 & AmeriFlux & (Chu et al., 2018) \\
\hline US-EML & USA & -149.254 & 63.8784 & AmeriFlux & (Belshe et al., 2012) \\
\hline
\end{tabular}




\begin{tabular}{|c|c|c|c|c|c|}
\hline US-FPe & USA & -105.102 & 48.3077 & LaThuile & (Ershadi et al., 2014) \\
\hline US-FR3 & USA & -97.99 & 29.94 & AmeriFlux & (Euskirchen et al., 2017) \\
\hline US-Fuf & USA & -111.762 & 35.089 & AmeriFlux & (Amiro et al., 2010) \\
\hline US-GLE & USA & -106.239 & 41.3644 & Fluxnet 2015 & fluxnet.ornl.gov \\
\hline US-GMF & USA & -73.2333 & 41.9667 & AmeriFlux & (Chu et al., 2018) \\
\hline US-Goo & USA & -89.8735 & 34.2547 & Fluxnet 2015 & fluxnet.ornl.gov \\
\hline US-Ha1 & USA & -72.1715 & 42.5378 & LaThuile & (Barford et al., 2001) \\
\hline US-Ho2 & USA & -68.747 & 45.2091 & LaThuile & (Wei et al., 2014) \\
\hline US-IB2 & USA & -88.241 & 41.8406 & AmeriFlux & (Allison et al., 2005) \\
\hline US-Ivo & USA & -155.75 & 68.4865 & AmeriFlux & (Euskirchen et al., 2017) \\
\hline US-Kon & USA & -96.5603 & 39.0824 & AmeriFlux & (Antunes et al., 2001) \\
\hline US-KS2 & USA & -80.6715 & 28.60858 & Fluxnet 2015 & fluxnet.ornl.gov \\
\hline US-KUT & USA & -93.1863 & 44.995 & AmeriFlux & (Euskirchen et al., 2017) \\
\hline US-Los & USA & -89.9792 & 46.0827 & Fluxnet 2015 & (Baker et al., 2003) \\
\hline US-Me1 & USA & -121.5 & 44.5794 & Fluxnet 2015 & (Irvine \& Hibbard, 2007) \\
\hline US-Me2 & USA & -121.557 & 44.4523 & Fluxnet 2015 & (Irvine \& Hibbard, 2007) \\
\hline US-MMS & USA & -86.4131 & 39.3231 & Fluxnet 2015 & (Baldocchi et al., 2001) \\
\hline US-MOz & USA & -92.2 & 38.7441 & LaThuile & (Stoy et al., 2013) \\
\hline US-Mpj & USA & -106.238 & 34.4384 & AmeriFlux & (Anderson-Teixeira et al., 2011) \\
\hline US-MRf & USA & -123.552 & 44.6465 & AmeriFlux & (Chu et al., 2018) \\
\hline US-Myb & USA & -121.765 & 38.0498 & AmeriFlux & (Baldocchi et al., 2018) \\
\hline US-Ne1 & USA & -96.4766 & 41.1651 & Fluxnet 2015 & fluxnet.ornl.gov \\
\hline US-NR1 & USA & -105.546 & 40.0329 & Fluxnet 2015 & (Albert et al., 2017) \\
\hline US-Oho & USA & -83.8438 & 41.5545 & Fluxnet 2015 & (Stoy et al., 2013) \\
\hline US-PFa & USA & -90.2723 & 45.9459 & LaThuile & (Keppel et al., 2012) \\
\hline US-Pon & USA & -97.1333 & 36.7667 & AmeriFlux & (Euskirchen et al., 2017) \\
\hline US-Prr & USA & -147.488 & 65.1237 & Fluxnet 2015 & (Ikawa et al., 2015) \\
\hline US-RC1 & USA & -117.078 & 46.7837 & AmeriFlux & (Chi et al, 2017a) \\
\hline US-RC3 & USA & -118.598 & 46.991 & AmeriFlux & (Chi et al, 2017a) \\
\hline US-RC4 & USA & -116.949 & 46.758 & AmeriFlux & (Chi et al, 2017a) \\
\hline US-RC5 & USA & -119.248 & 47.01 & AmeriFlux & (Chi et al, 2017b) \\
\hline US-RIs & USA & -116.736 & 43.1439 & AmeriFlux & (Euskirchen et al., 2017) \\
\hline US-Ro1 & USA & -93.0898 & 44.7143 & AmeriFlux & (Baker et al., 2003) \\
\hline US-SCd & USA & -116.372 & 33.6518 & AmeriFlux & (Euskirchen et al., 2017) \\
\hline US-SCf & USA & -116.772 & 33.8079 & AmeriFlux & (Euskirchen et al., 2017) \\
\hline US-SCs & USA & -117.696 & 33.7343 & AmeriFlux & (Euskirchen et al., 2017) \\
\hline US-Sdh & USA & -101.407 & 42.0693 & AmeriFlux & (Billesbach and Arkebauer, 2004) \\
\hline US-Ses & USA & -106.744 & 34.3349 & AmeriFlux & (Anderson-Teixeira et al., 2011) \\
\hline US-SFP & USA & -96.902 & 43.2408 & AmeriFlux & (Euskirchen et al., 2017) \\
\hline US-Shd & USA & -96.6833 & 36.9333 & AmeriFlux & (Burba et al., 2001) \\
\hline US-Skr & USA & -81.0776 & 25.3629 & AmeriFlux & (Barr et al., 2013) \\
\hline US-SIt & USA & -74.596 & 39.9138 & AmeriFlux & (Chu et al., 2018) \\
\hline US-SP1 & USA & -82.2188 & 29.7381 & AmeriFlux & (Burton et al., 2002) \\
\hline
\end{tabular}




\begin{tabular}{|c|c|c|c|c|c|}
\hline US-SP2 & USA & -82.2448 & 29.7648 & LaThuile & (Castro et al., 2000) \\
\hline US-SP3 & USA & -82.1633 & 29.7548 & AmeriFlux & (Castro et al., 2000) \\
\hline US-SRM & USA & -110.866 & 31.8214 & AmeriFlux & (Barron-Gafford et al., 2013) \\
\hline US-Srr & USA & -122.026 & 38.2006 & AmeriFlux & (Chu et al., 2018) \\
\hline US-SuW & USA & -156.491 & 20.8246 & AmeriFlux & (Anderson et al., 2015) \\
\hline US-Syv & USA & -89.3477 & 46.242 & Fluxnet 2015 & (Chu et al., 2018) \\
\hline US-Twt & USA & -121.652 & 38.1055 & Fluxnet 2015 & (Baldocchi et al., 2018) \\
\hline US-UMd & USA & -84.6975 & 45.5625 & AmeriFlux & (Chu et al., 2018) \\
\hline US-Var & USA & -120.951 & 38.4133 & Fluxnet 2015 & (Baldocchi et al., 2004) \\
\hline $\begin{array}{l}\text { US- } \\
\text { WBW }\end{array}$ & USA & -84.2874 & 35.9588 & LaThuile & (Baldocchi et al., 2004) \\
\hline US-WCr & USA & -90.0799 & 45.8059 & Fluxnet 2015 & (Baker et al., 2003) \\
\hline US-Wdn & USA & -106.262 & 40.7838 & AmeriFlux & (Euskirchen et al., 2017) \\
\hline US-Whs & USA & -110.052 & 31.7438 & AmeriFlux & (Biederman, et al., 2016) \\
\hline US-Wi4 & USA & -91.1663 & 46.7393 & LaThuile & (Hilton et al., 2014) \\
\hline US-Wi6 & USA & -91.2982 & 46.6249 & Fluxnet 2015 & (Noormets et al., 2007) \\
\hline US-Wjs & USA & -105.862 & 34.4255 & AmeriFlux & (Anderson-Teixeira et al., 2011) \\
\hline US-Wkg & USA & -109.942 & 31.7365 & Fluxnet 2015 & (Biederman, et al., 2016) \\
\hline US-Wrc & USA & -121.952 & 45.8205 & AmeriFlux & (Chu et al., 2018) \\
\hline RU-YLF & Russia & 129.2414 & 62.255 & AsiaFlux & asiaflux.net \\
\hline RU-YPF & Russia & 129.6506 & 62.24139 & AsiaFlux & asiaflux.net \\
\hline ZA-Kru & South Africa & 31.4969 & -25.0197 & LaThuile & (King et al., 2003) \\
\hline ZM-Mon & Zambia & 23.25278 & -15.4378 & Fluxnet 2015 & (King et al., 2003) \\
\hline
\end{tabular}

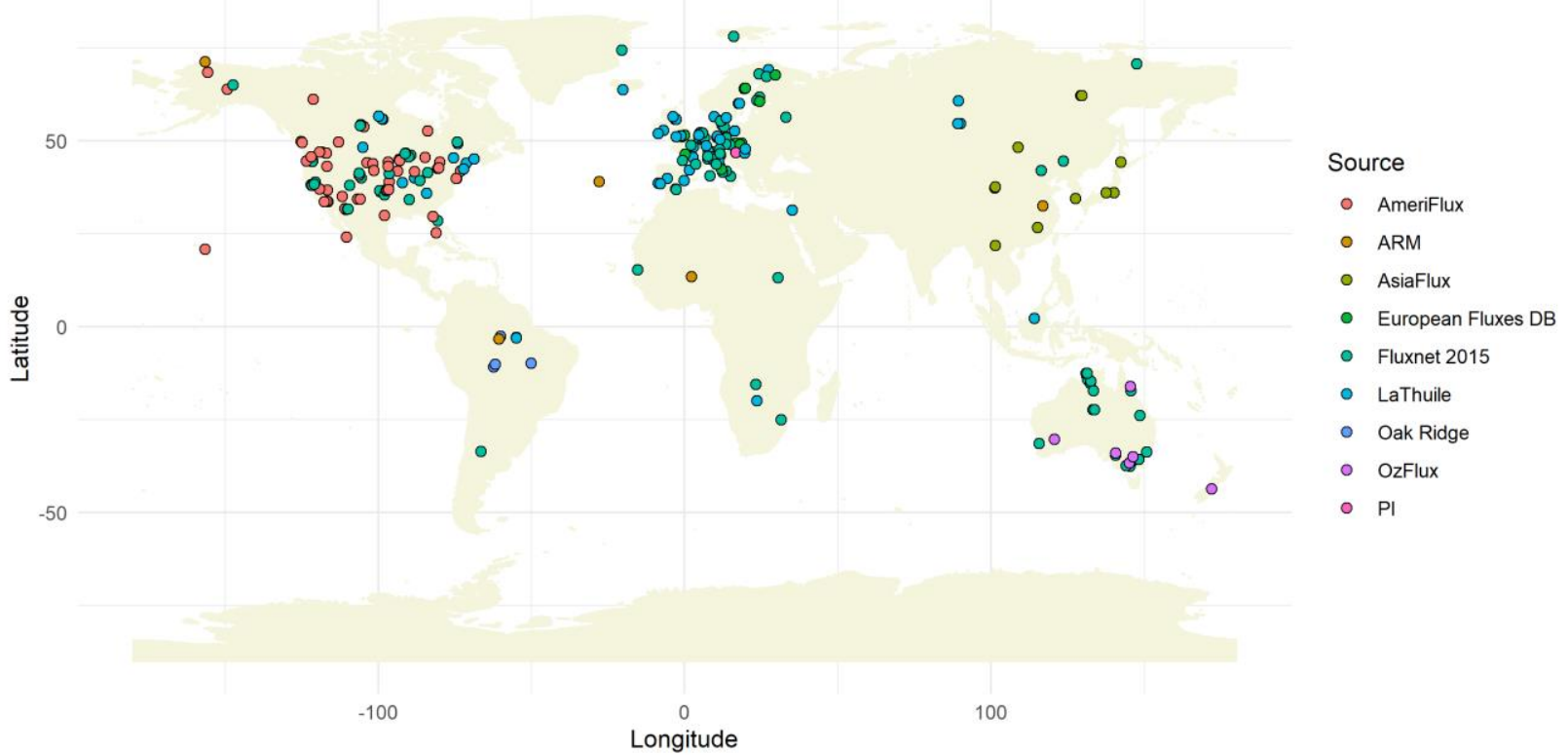

11

12

13

14
Figure S1: Location of the 260 sites used to derive and validate DOLCE V2, color-coded by data source. Data source includes Ameriflux (ameriflux.Ibl.gov), the Atmospheric Radiation Measurement (ARM; arm.gov), AsiaFlux (asiaflux.net), European Fluxes Database (europe-fluxdata.eu), Fluxnet 2015, LaThuile 
15 Free Fair Use (fluxnet.fluxdata.org), Oak Ridge data repository (daac.ornl.gov), OzFlux (ozflux.org.au) and 16 individual site principal investigators (PI).

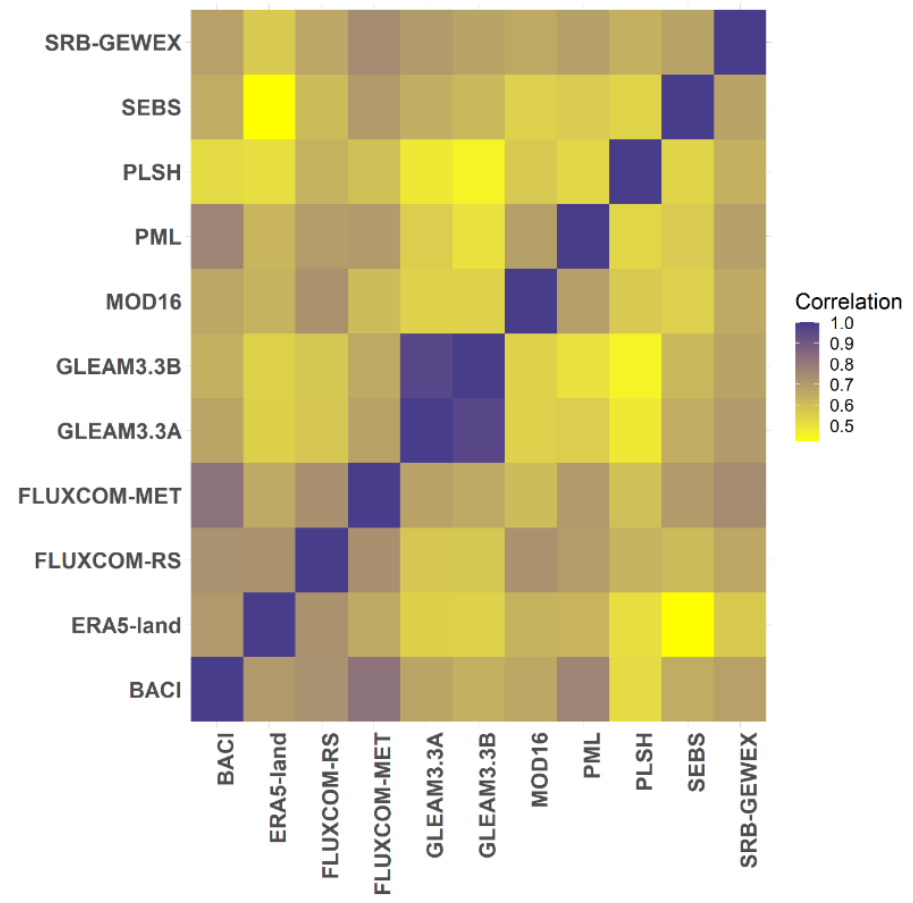

19 Figure S2: Error correlation between the participating parent datasets of DOLCE V2 when compared to 20 in-situ data from 260 sites. Large correlation (>0.5) between two datasets indicates that their errors are 21 highly dependent. 


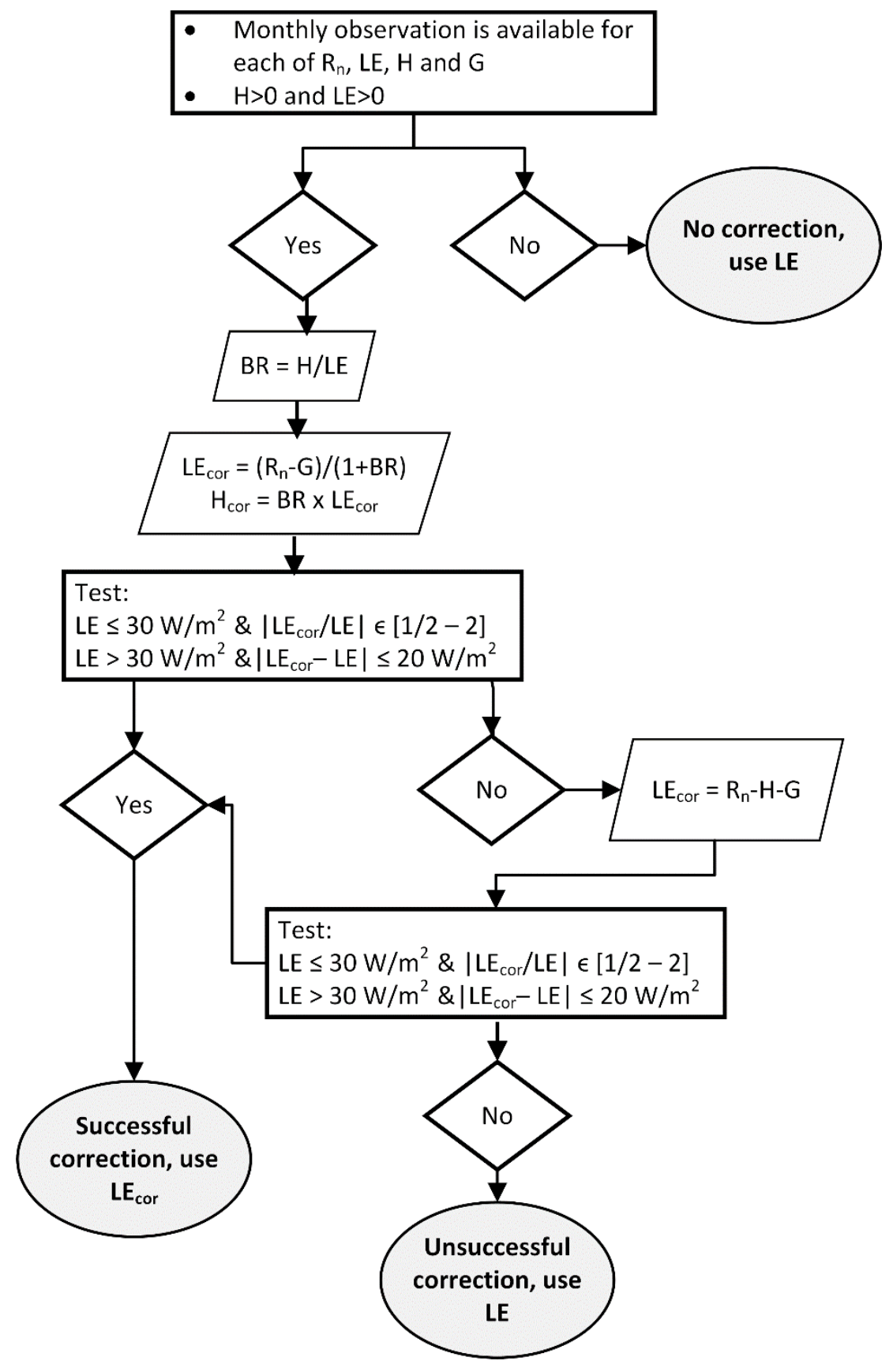

Figure S3: Flowchart illustrating the correction steps carried out for every monthly record of observed LE at the flux tower sites to correct for energy balance non-closure.

\section{S2. Global ET datasets}

Table S2: Access information and download data of the global ET datasets (also referred to as parent datasets) used to develop DOLCE V2 and DOLCE V3.

32 


\begin{tabular}{|c|c|c|}
\hline $\mathrm{BACl}$ & https://doi.org/10.17871/BACl.224 & 03-10-2019 \\
\hline ERA5-land & https://doi.org/10.24381/cds.e2161bac & 05-06-2020 \\
\hline FLUXCOM-RS & $\begin{array}{l}\text { https://doi.org/10.17871/FLUXCOM EnergyFluxes v1 } \\
\text { LE.RS.EBC-BWR.MLM-ANN.METEO-NONE.4320_2160.monthly }\end{array}$ & $02-10-2019$ \\
\hline $\begin{array}{l}\text { FLUXCOM-MET } \\
\text { or FLUXCOM- } \\
\text { METa }\end{array}$ & $\begin{array}{l}\text { https://doi.org/10.17871/FLUXCOM EnergyFluxes v1 } \\
\text { LE.RS_METEO.EBC-BWR.MLM-MARS.METEO-GSWP3.720_360.monthly }\end{array}$ & 02-10-2019 \\
\hline $\begin{array}{l}\text { FLUXCOM-MET } \\
\text { FLUXCOM- } \\
\text { METb }\end{array}$ & $\frac{\text { https://doi.org/10.17871/FLUXCOM EnergyFluxes_v1 }}{\text { LE.RS_METEO.EBC-ALL.MLM-ALL.METEO-CRUNCEP_v8.720_360.monthly }}$ & $15-03-2021$ \\
\hline GLEAM3.3A & www.GLEAM.eu & 02-09-2019 \\
\hline GLEAM3.3B & $\underline{\text { www.GLEAM.eu }}$ & 02-09-2019 \\
\hline GLEAM3.5A & www.GLEAM.eu & $18-03-2021$ \\
\hline GLEAM3.5B & www.GLEAM.eu & $18-03-2021$ \\
\hline MOD16 & $\begin{array}{l}\text { http://files.ntsg.umt.edu/data/NTSG Products/MOD16/ } \\
\text { MOD16A2_MONTHLY.MERRA_GMAO_1kmALB/GEOTIFF_0.05degree/ }\end{array}$ & 01-10-2019 \\
\hline PML & https://data.csiro.au/collections/\#collection/CIcsiro:17375v2 & 09-04-2019 \\
\hline PLSH & http://files.ntsg.umt.edu/data/ET global monthly/Global_8kmResolution/ & 30-09-2019 \\
\hline SEBS & http://en.tpedatabase.cn/portal/MetaDatalnfo.jsp?MetaDatald=249454 & 09-04-2019 \\
\hline SRB-GEWEX & https://disc.gsfc.nasa.gov/datasets/WC PM ET 050 1/summary & 01-10-2019 \\
\hline
\end{tabular}

S3. Weighting groups

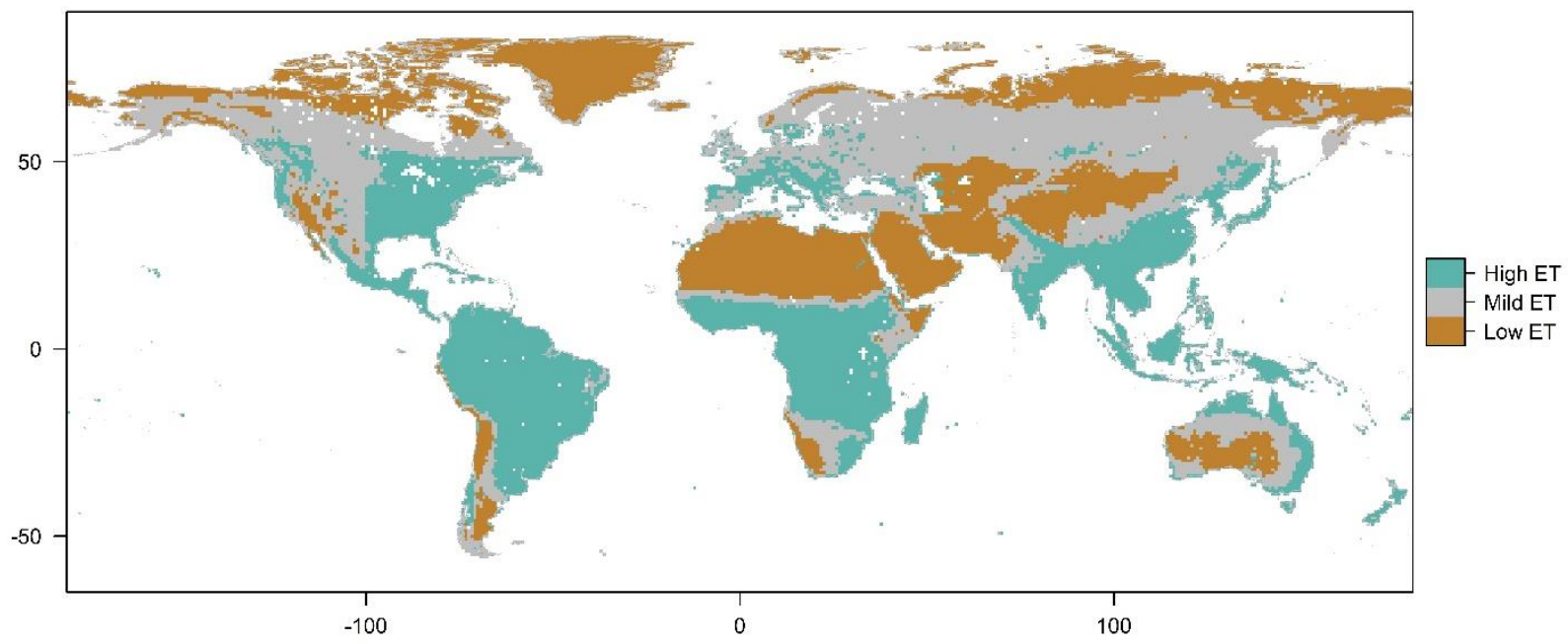

Figure S4: Classification of the land into three distinct broad ET regimes according to two aspects of ET, mean annual total ET and within-year relative variability throughout $1980-2018$, derived from GLEAM V3.5a, and using K-means unsupervised classification.

\section{S4. Bias correction strategies}

In DOLCE V1, we showed that part of the success of the weighting approach is due to the bias correction applied before the weighting. Within each tier, the bias correction is applied simply by adding the mean difference between a product and tower data uniformly to all values of a product before the weights are derived - it is constant in space and time for a given product within one tier. The grouping strategies detailed above examine the effect of considering different bias correction and weighting subgroups 
47 within each spatiotemporal tier, with groups divided by region (continents, latitudes, or ET regimes)

48 or/and seasons. As an alternative to the grouping strategies, we also investigate if deriving a spatially

49 varying bias correction within each tier could further improve the weighting. A spatially varying bias

50 correction might better capture the performance deficiencies of each the parent datasets.

51

52 To derive a global bias correction for a particular parent dataset within each tier, we first compute the

53 mean bias at each flux tower site across all the time records within the tier. We then assign those ET

54 bias values, or bias field, to the grid cells containing the sites. Finally, using the bias values at these grid

55 cells, we extrapolate the bias field spatially to the entire global land domain within the tier using several

56 different extrapolation strategies, including inverse distance weighting (IDW), local polynomial

57 interpolation and nearest neighbourhood. As with the different weighting groups, we test the

58 effectiveness of each approach using out-of-sample tests. The hybrid ET estimates derived by

59 implementing spatially varying bias correction strategies failed to outperform the parent datasets in the

60 out-of-sample site tests. Figure S5 shows the results of out-of-sample tests for the bias correction

61 approach that uses IDW. 
(a) RMSE

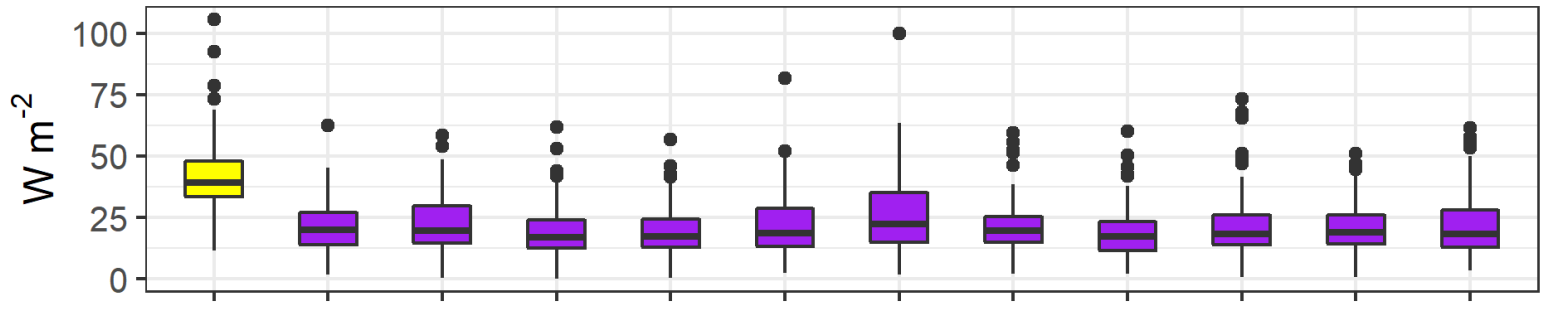

(b) Standard deviation difference

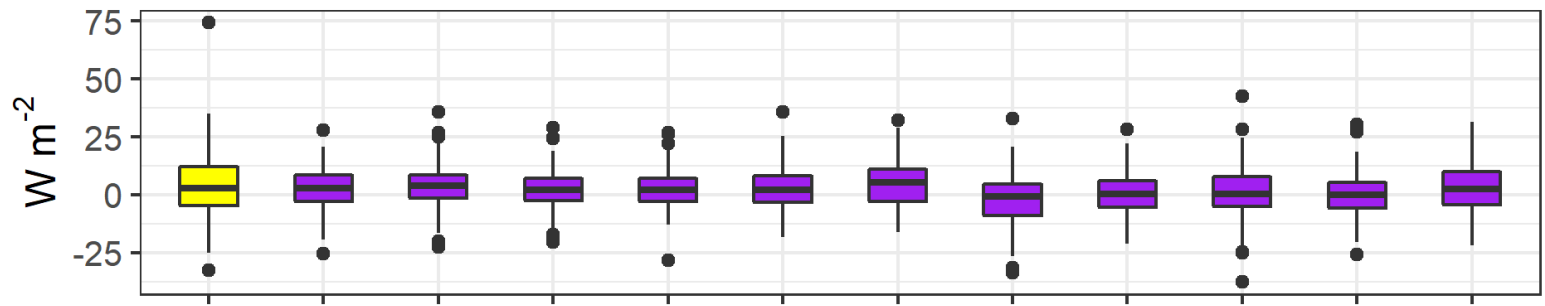

(c) Correlation

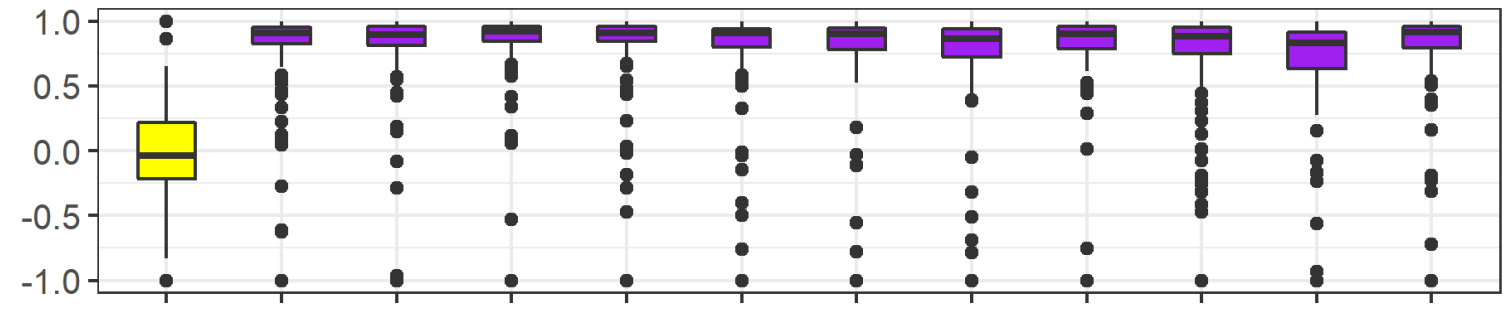

(d) Mean absolute deviation

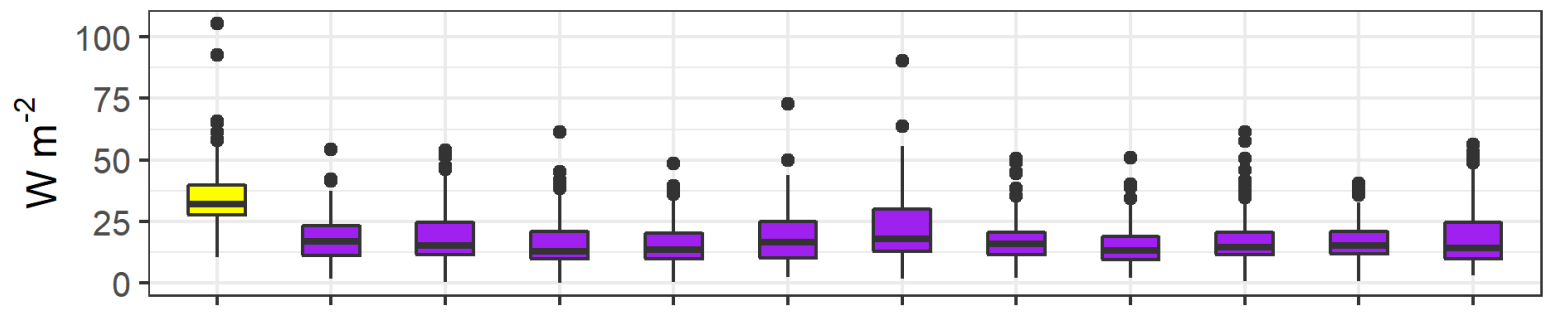

(e) Median absolute deviation

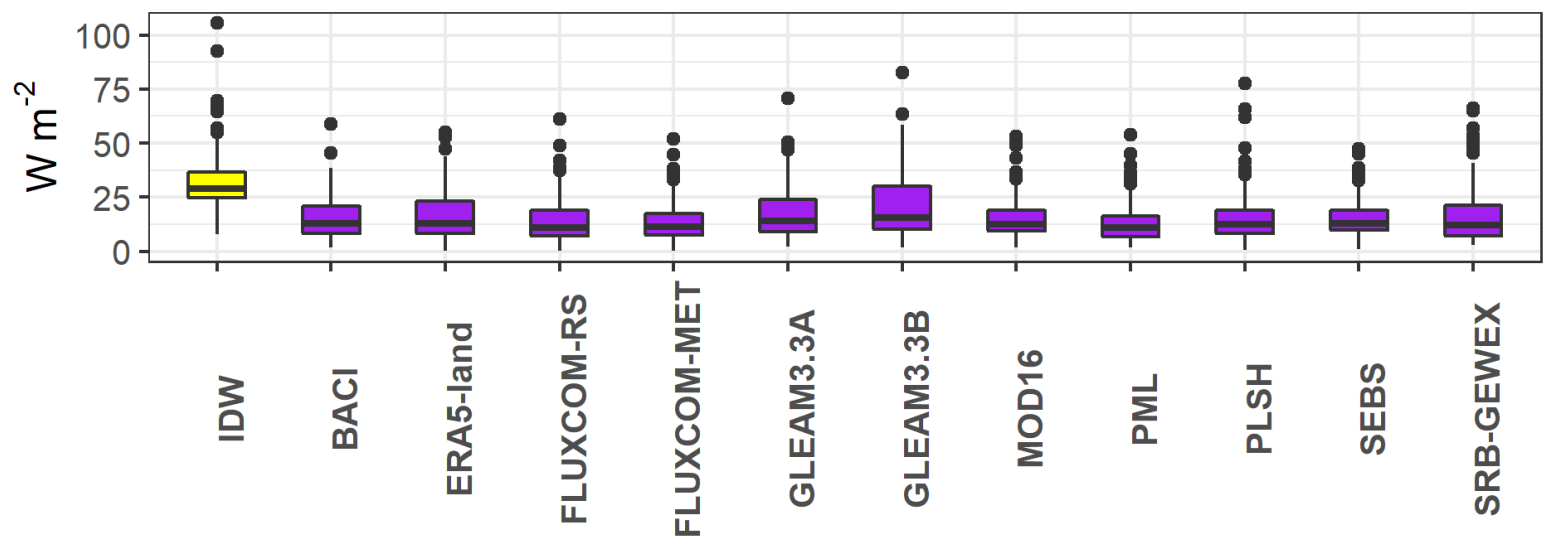


Figure S5: Results of the out-of-sample test across five metrics of performance, (a) RMSE, (b) Correlation (c) Standard deviation difference, (d) Mean absolute deviation, and (e) Median absolute deviation. Box plots represent spread over 1000 different selections of out-of-sample sites. The yellow box plot represents the performance results of weighting using IDW bias correction strategy, while the purple boxplots represent performance results of the parent datasets.

\section{S5. Performance of weighting group strategies}

The results of out-of-sample performance of different grouping strategies (including no grouping) against the 11 parent datasets of DOLCE V2 (left column) are presented in Fig. S6. The performance results across all 1000 different random site samples are shown in a boxplot for each clustering method (yellow), non-clustered weighting (as per DOLCE V1, in magenta, labelled NO.GROUPING), and each parent dataset (purple). The hybrid ET estimates derived from grouped weighting are labelled LAT.ZONES, CONTINENTS, SEASONS, MONTHS, and HEMISPHERE, following the grouping approaches outlined above. The plots in the left column show that overall, the hybrid ET estimates outperform their 11 parent datasets across all the performance metrics and in all clustering settings. To highlight the differences between the grouping strategies, we magnify the leftmost section of these plots in the right column of Fig. S6, and we also show in red the median value of each boxplot. Results only change slightly across the grouping approaches, with the best results achieved by grouping weights by months. Despite the relatively small improvement offered by this strategy at the out-of-sample sites over the other grouping strategies, we derive DOLCE V2 (Hobeichi, 2020) by applying a grouped weighting by months. We recall that in this approach, the observational and gridded ET data are split into two groups, one covering the period June - November and the other covering December - May. Weighting and bias correction is then implemented in each group separately for each tier to create the subsets from which the hybrid ET product is derived. 
(a) RMSE

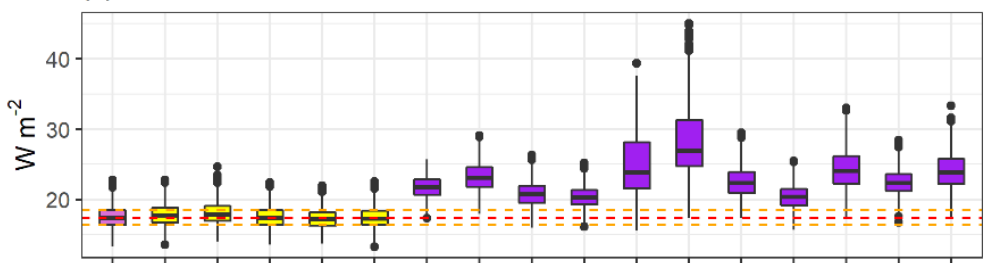

(b) Standard deviation difference

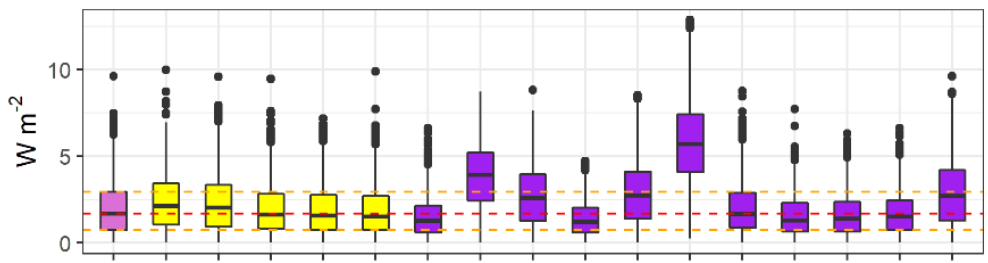

(c) Correlation

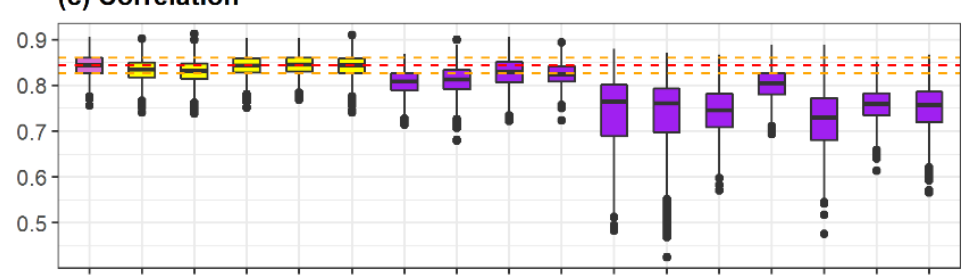

(d) Mean absolute deviation

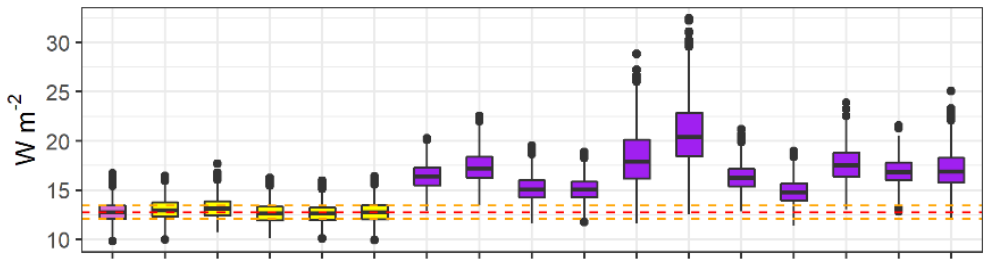

(e) Median absolute deviation

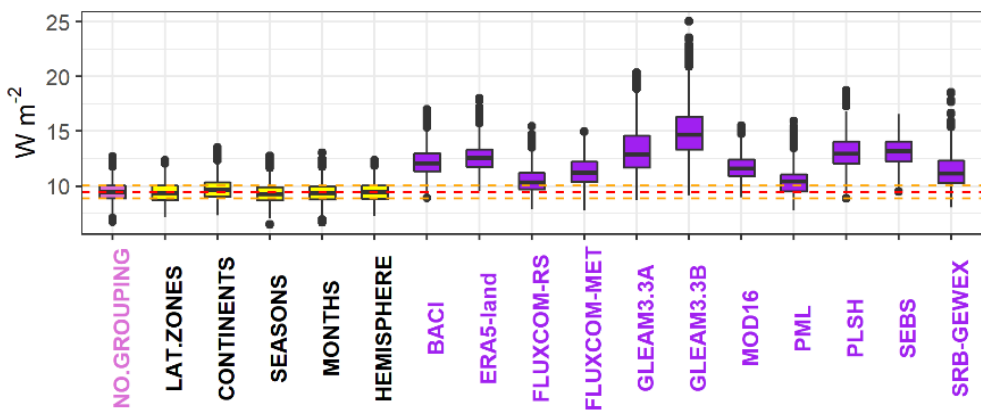

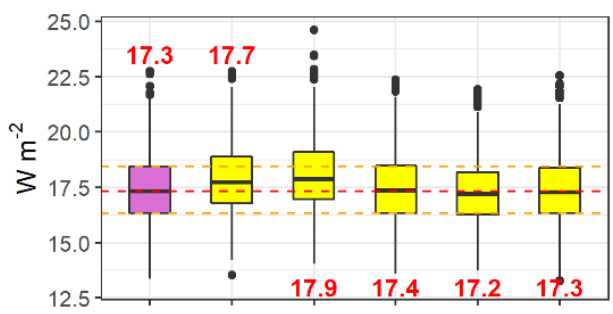
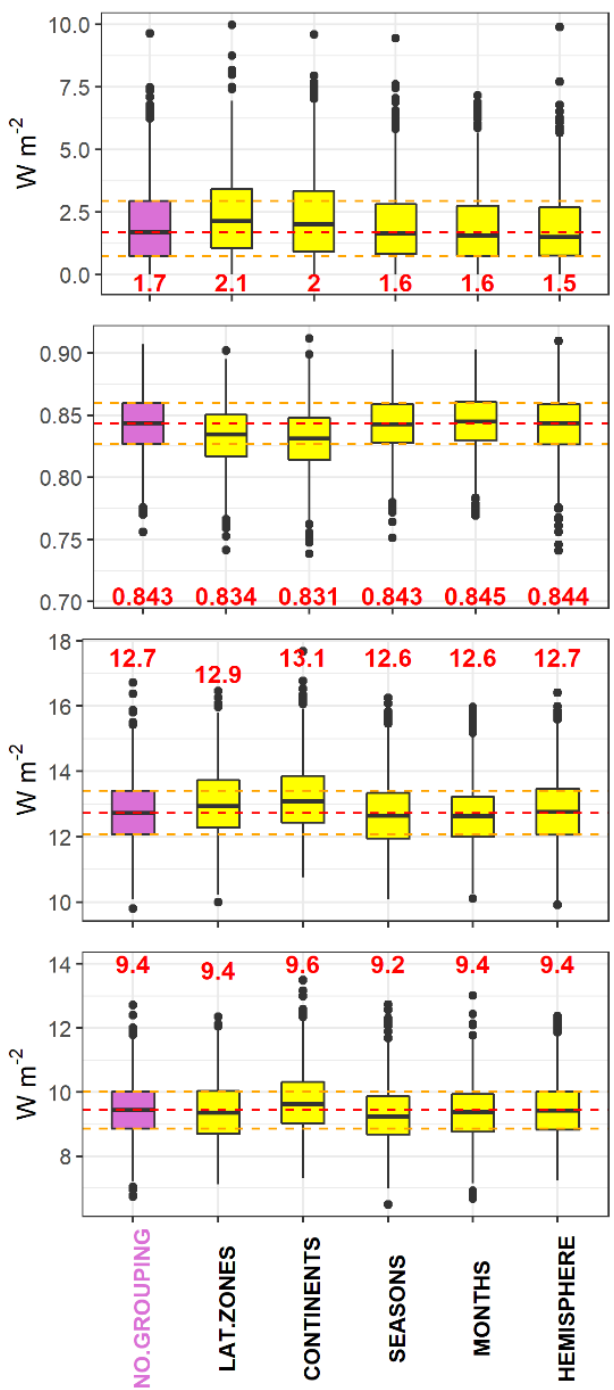

Figure S6: Results of the out-of-sample test across five metrics of performance, (a) RMSE, (b) Correlation (c) Standard deviation difference, (d) Mean absolute deviation, and (e) Median absolute deviation. Box plots represent spread over 1000 different selections of out-of-sample sites. Different clustering methods (yellow) include: no clustering (NO.GROUPING; shown in magenta and horizontal dashed lines), by latitude (LATZONES), by continents (CONTINENTS), by seasons (SEASONS), by months (MONTHS), and by hemisphere (HEMISPHERE), the red text marks the median values. Performance comparison with each of the parent datasets is shown in purple. 
96 The box plots in Fig. 57 show the ratio $\frac{\text { Uncertainty }_{\text {in-sample }}}{\text { Uncertainty }_{\text {out-sample' }}}$ obtained across the different grouping

97 techniques. Each boxplot represents this ratio from all sites out of sample and shows that over half of

98 the data, the ratio ranges between 0.83 and 1.51 , with a median very close to 1 . This confirms that,

99 overall, when the uncertainty estimates are computed out of sample, they are very similar to what they

100 would have been if they were computed in sample. Also, the fact the shift in ratio is mostly towards

101 values bigger than 1 rather than smaller than 1 indicates that Uncertainty ${ }_{\text {in-sample }}$ is greater than

102 Uncertainty $_{\text {out-sample }}$ so that uncertainty is overestimated rather than underestimated. Interestingly,

103 the lower (0.86) and upper (1.46) quartiles achieved by grouping weighting by months are the closest to 1041 than the other grouping techniques. This suggests that overall, grouping weighting by months is able 105 to derive slightly more robust uncertainty estimates than the other techniques.

106

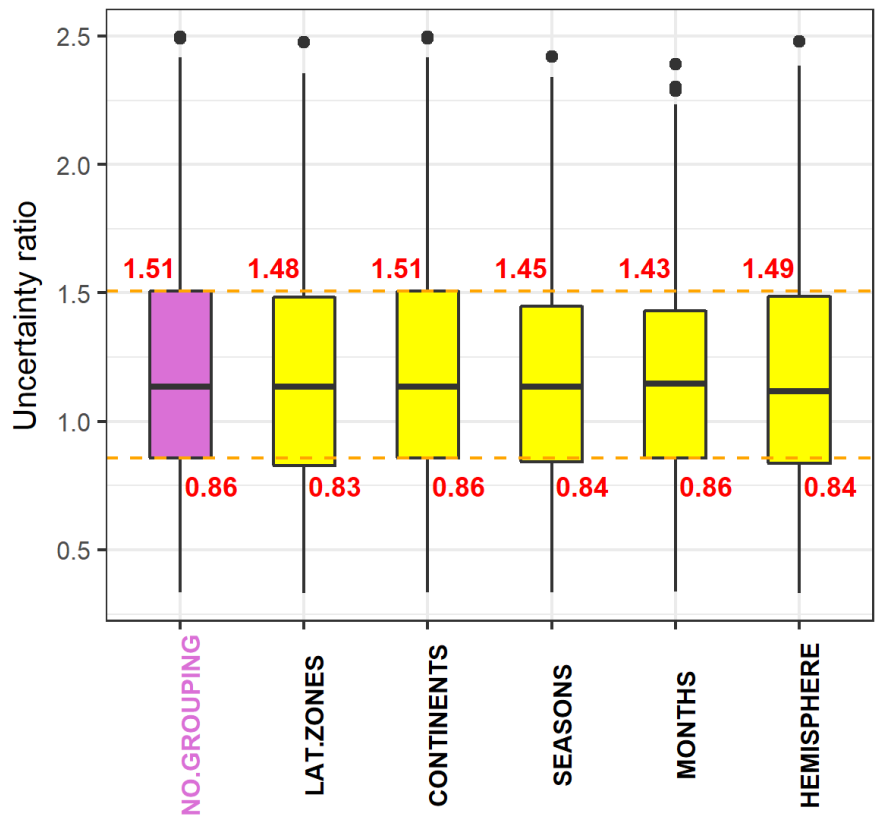

Figure S7: Box and whisker plots displaying the ratio $\frac{\text { Uncertaint }_{\text {in-sample }}}{\text { Uncertaint }_{\text {out-sample }}}$, computed for each site using the clustering methods defined in Sect. 2.2.4. Labeling and colors are as in Fig. S6. Red text marks the value of the upper quantile (75\%) and lower quantile (25\%). 


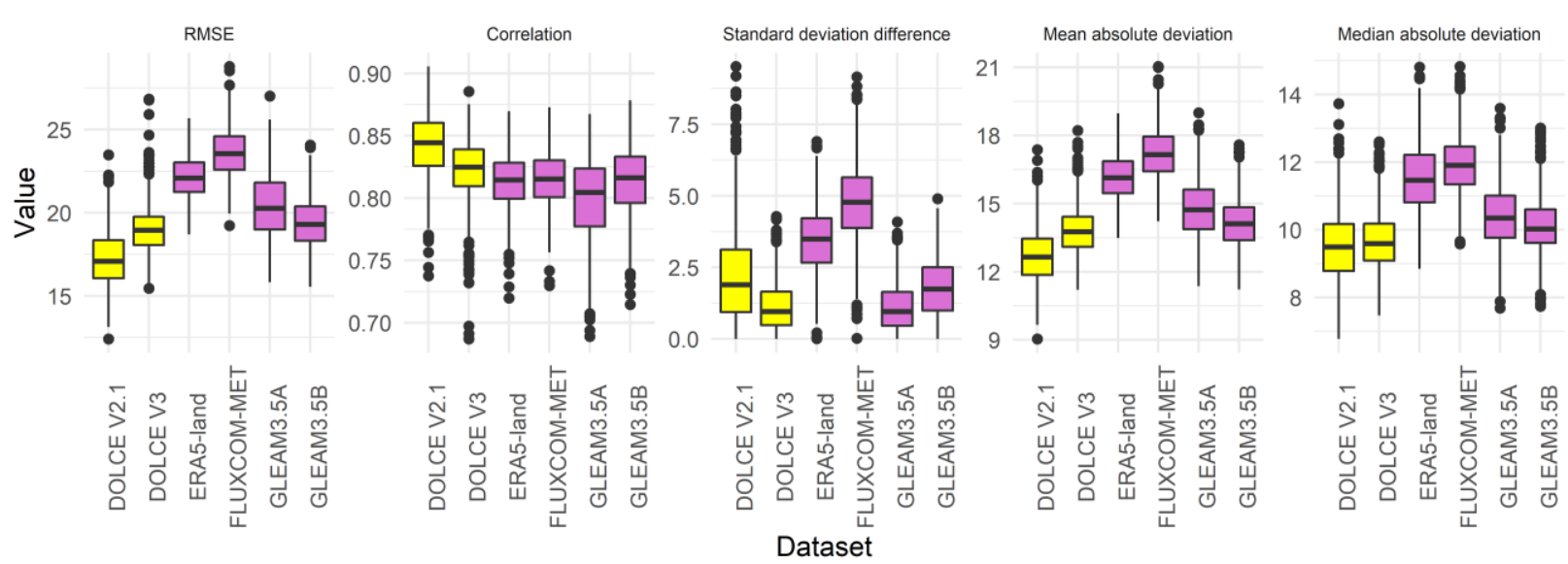

112

113

114

115

116

117

118

119

120

121

122

123

Figure S8: Results of the out-of-sample test comparing DOLCE V3 with DOLCE V2.1 (both in yellow) and each of its parent datasets (purple) across five metrics of performance, RMSE, Correlation, Standard deviation difference, Mean absolute deviation, and Median absolute deviation. Box plots represent spread over 1000 different selections of out-of-sample sites.

\section{S6. Comparison of DOLCE V3 with its parent datasets}

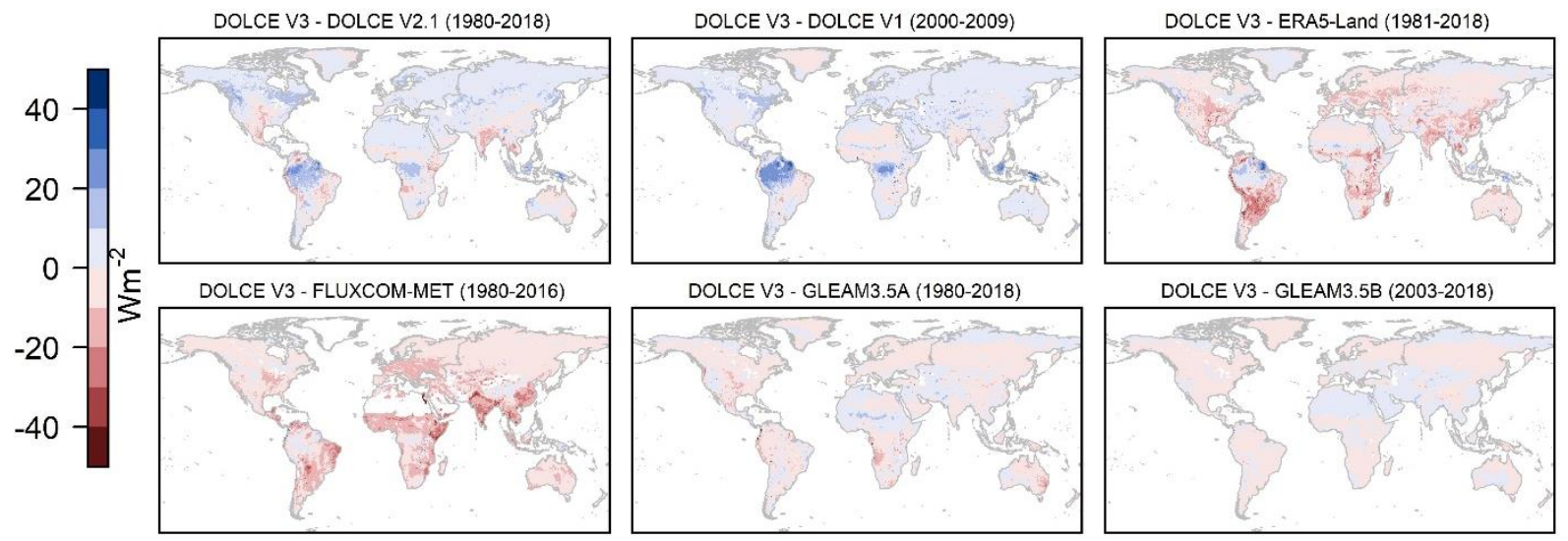

Figure S9: Spatial distribution of differences in ET climatology between DOLCE V3 and each of its parent datasets and DOLCE V2. Different spatiotemporal masks are applied for each comparison based on the spatiotemporal coverage of DOLCE V3 and the other datasets. 


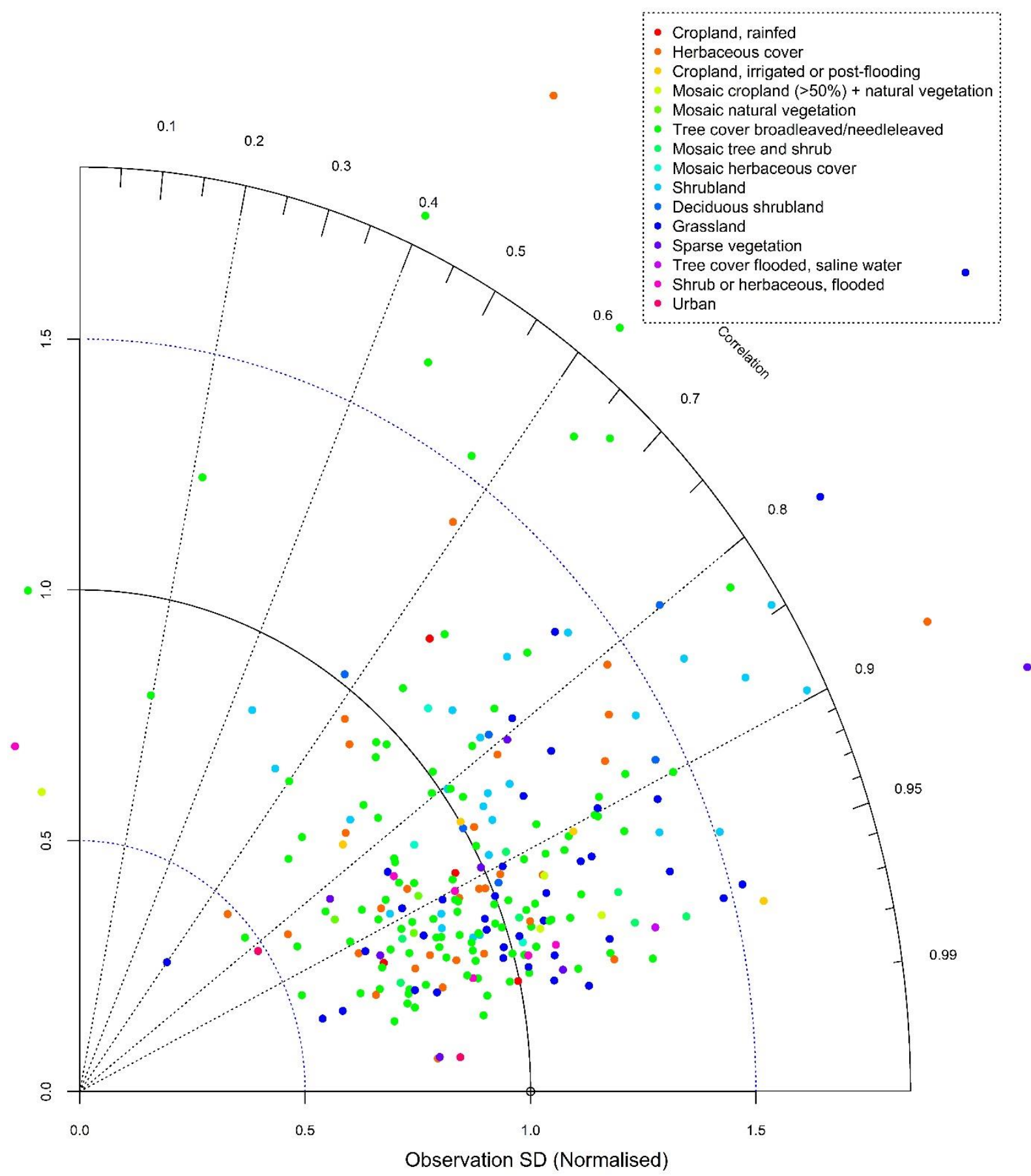

Figure S10: Taylor Diagram displaying two statistical metrics i.e., correlation and standard deviation of DOLCE V2 relative to normalised observational data presented by a hollow point (reference point) at one unit on the $x$-axis. Statistics points are color-coded by the land cover of the sites they represent. Land covers at the site locations are based on land cover maps from the European Space Agency (ESA; 
http://www.esa.int/). All broadleaved and needleleaved tree covers were combined together in a single land cover 'Tree cover broadleaved/needleleaved'.

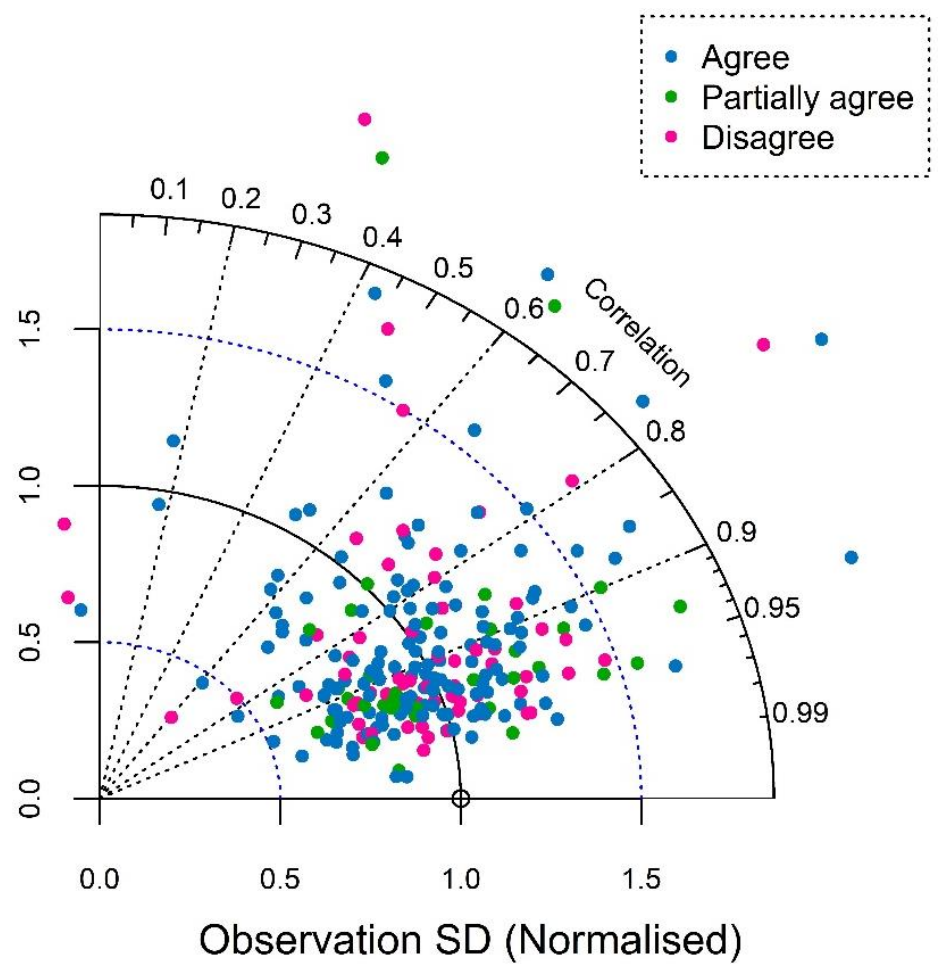

Figure S11: Taylor Diagram displaying two statistical metrics i.e., correlation and standard deviation of DOLCE V2 relative to normalised observational data presented by a hollow point (reference point) at one unit on the $x$-axis. Blue points represent sites whose land types match the dominant land types of the underlying grid-cells; green points represent sites whose land types cover more than $25 \%$ of the underlying grid-cells without being the dominant land cover at these grid-cells; and pink points representing sites whose land types covers less than $25 \%$ of the underlying grid-cells. Land cover types at the sites' footprint and the underlying grid-cells are determined based on land cover maps from the European Space Agency.

\section{S8. Comparison of DOLCE V2 with DOLCE V1 and Conserving Land Atmosphere Synthesis Suite (CLASS-ET)}

Table S3: Area weighted mean ET $\left(\mathrm{Wm}^{-2}\right)$ computed for DOLCE V2, DOLCE V1 and CLASS-ET and averaged over each of Africa, Australia, Eurasia, North America, South America and the global land excluding Antractica. The differences between DOLCE V2 and each of DOLCE V1 and CLASS-ET are shown in columns 5 and 6 respectively.

\begin{tabular}{|l|c|c|c|c|c|}
\hline & DOLCE V2 & DOLCE V1 & CLASS & DOLCE V2 - DOLCE V1 & DOLCE V2 - CLASS \\
\hline Africa & 40.1 & 35.8 & 36.3 & 4.3 & 3.8 \\
\hline
\end{tabular}




\begin{tabular}{|l|c|c|c|c|c|}
\hline Australia & 25.4 & 23 & 26.1 & 2.4 & -0.7 \\
\hline Eurasia & 29.3 & 28 & 27.7 & 1.3 & 1.6 \\
\hline North America & 33.2 & 30.5 & 31.1 & 2.7 & 2.1 \\
\hline South America & 73.3 & 68.3 & 71.2 & 5 & 2.1 \\
\hline $\begin{array}{l}\text { Global land } \\
\text { excluding } \\
\text { Antarctica }\end{array}$ & 38.4 & 35.7 & 36.3 & 2.7 & 2.1 \\
\hline
\end{tabular}

\section{S9. ET regimes}

Table S4: List of 6 ET regimes identified by unsupervised learning. Second column shows the abbreviation given to each regime. Third and fourth columns display the statistics of the class's centroid: Yearly ET total climatology (column 3) and relative within-year standard deviation of monthly ET 156 climatology (column 4).

\begin{tabular}{|l|l|l|l|}
\hline Regime description & Regime abbreviation & $\begin{array}{l}\text { Yearly ET total } \\
\text { climatology (mm) }\end{array}$ & $\begin{array}{l}\text { Relative standard } \\
\text { deviation (\%) }\end{array}$ \\
\hline Very low ET with high variability & V.L.ET, H.variability & 60 & 10.5 \\
\hline Low ET with high variability & L.ET, H.variability & 250.8 & 8.7 \\
\hline $\begin{array}{l}\text { Mild low ET with medium } \\
\text { variability }\end{array}$ & M.L.ET, M.variability & 435.4 & 7.2 \\
\hline $\begin{array}{l}\text { Mild high ET with medium } \\
\text { variability }\end{array}$ & M.H.ET, M.variability & 680.3 & 4.7 \\
\hline $\begin{array}{l}\text { High ET with low variability } \\
\text { Very high ET with low variability }\end{array}$ & H.E.E. L. & & 2.7 \\
\hline
\end{tabular}

\section{S10. References}

Albert, L. P., Keenan, T. F., Burns, S. P., Huxman, T. E., and Monson, R. K.: Climate Controls Over Ecosystem Metabolism: Insights From A Fifteen-Year Inductive Artificial Neural Network Synthesis For A Subalpine Forest, Oecologia, 184(1), 25-41, 2017.

Allison, V. J., Miller, R. M., Jastrow, J. D., Matamala, R., Zak, D. R.: Changes In Soil Microbial Community Structure In A Tallgrass Prairie Chronosequence, Soil Science Society Of America Journal, 69(5), 1412-1421, 2005.

Amiro, B. D., Barr, A. G., Barr, J. G., Black, T. A., Bracho, R., Brown, M., Chen, J., Clark, K. L., Davis, K. J., Desai, A. R., Dore, S., Engel, V., Fuentes, J. D., Goldstein, A. H., Goulden, M. L., Kolb, T. E., Lavigne, M. B., Law, B. E., Margolis, H. A., Martin, T., 
McCaughey, J. H., Misson, L., Montes-Helu, M., Noormets, A., Randerson, J. T., Starr, and G., Xiao, J.: (2010) Ecosystem Carbon Dioxide Fluxes After Disturbance In Forests Of North America, J. Geophys. Res. Atmos., 115(G00K02).

Anderson, R. G., Tirado-Corbalá, R., Wang, D., and Ayars, J. E.: Long-Rotation Sugarcane In Hawaii Sustains High Carbon Accumulation And Radiation Use Efficiency In 2nd Year Of Growth, Agriculture, Ecosystems \&amp; Environment, 199, 216-224, 2015.

Anderson-Teixeira, K. J., Delong, J. P., Fox, A. M., Brese, D. A., and Litvak, M. E.: Differential Responses Of Production And Respiration To Temperature And Moisture Drive The Carbon Balance Across A Climatic Gradient In New Mexico, Glob. Chang. Biol., 17(1), 410-424, 2011.

Andrykanus, R.: Howard Springs Understory_old_20131128 OzFlux: Australian and New Zealand Flux Research and Monitoring hdl: 102.100.100/14224, 2012.

Antunes, M. A. H., Walter-Shea, E. A., and Mesarch, M. A.: Test Of An Extended Mathematical Approach To Calculate Maize Leaf Area Index And Leaf Angle Distribution, Agric. For. Meteorol., 108(1), 45-53, 2001.

Arain, M. A. and Restrepo-Coupe, N.: Net Ecosystem Production In A Temperate Pine Plantation In Southeastern Canada, Agric. For. Meteorol., 128(3-4), 223-241, 2005.

Bagley, J. E., Kueppers, L. M., Billesbach, D. P., Williams, I. N., Biraud, S. C., and Torn, M. S.: The Influence Of Land Cover On Surface Energy Partitioning And Evaporative Fraction Regimes In The U.S. Southern Great Plains, J. Geophys. Res. Atmos.: Atmospheres, 122(11), 5793-5807, 2017.

Atmospheric Radiation Measurement (ARM) user facility, updated hourly. Eddy Correlation Flux Measurement System (30ECOR). 1997-04-25 to 2004-03-31, Southern Great Plains (SGP) Smileyberg, KS (ABLE) (A4). Compiled by R. Sullivan, M. Pekour and E. Keeler. ARM Data Center. Data set accessed 2019-09-17 at doi:10.5439/1025039, 1997. Atmospheric Radiation Measurement (ARM) user facility updated hourly. Quality Controlled Eddy Correlation Flux Measurement (30QCECOR). 2005-11-26 to 2007-01-07, ARM Mobile Facility (NIM) Niamey, Niger (M1). Compiled by R. McCoy, S. Xie and Y. Zhang. ARM Data Center. Data set accessed 2019-09-17 at doi:10.5439/1097546, 2005. Atmospheric Radiation Measurement (ARM) user facility, updated hourly. Quality Controlled Eddy Correlation Flux Measurement (30QCECOR). 2008-05-06 to 2008-12-28, ARM Mobile Facility (HFE) Shouxian, Anhui, China (M1). Compiled by R. McCoy, S. Xie and Y. Zhang. ARM Data Center. Data set accessed 2019-09-17 at doi:10.5439/1097546, 2008. Atmospheric Radiation Measurement (ARM) user facility, updated hourly. Quality Controlled Eddy Correlation Flux Measurement (30QCECOR). 2009-04-15 to 2010-09-30, ARM Mobile Facility (GRW) Graciosa Island, Azores, Portugal; AMF1 (M1). Compiled by R. McCoy, S. Xie and Y. Zhang. ARM Data Center. Data set accessed 2019-09-17 at doi:10.5439/1097546, 2009.

Atmospheric Radiation Measurement (ARM) user facility, updated hourly. Quality Controlled Eddy Correlation Flux Measurement (30QCECOR). 2011-09-16 to 2020-05-11, North Slope Alaska (NSA) Barrow, Alaska (71.325, -156.608, 5) (E10). Compiled by R. McCoy, S. Xie and Y. Zhang. ARM Data Center. Data set accessed 2019-09-17 at doi:10.5439/1097546, 2011. Atmospheric Radiation Measurement (ARM) user facility, updated hourly. Eddy Correlation Flux Measurement System (30ECOR). 2013-12-05 to 2015-01-10, Tropical Western Pacific (TWP) East Arm, Darwin, Australia (E30). Compiled by R. Sullivan, D. Cook and E. Keeler. ARM Data Center. Data set accessed 2019-09-17 at doi:10.5439/1025039, 2013.

Aurela, M., Laurila, T. and Tuovinen, J.-P.: Seasonal CO2 balances of a subarctic mire, J. Geophys. Res. Atmos., 106(D2), 16231637, doi:10.1029/2000JD900481, 2001.

Baker, I., Denning, A. S., Hanan, N., Prihodko, L., Uliasz, M., Vidale, P., Davis, and K., Bakwin, P.: Simulated And Observed Fluxes Of Sensible And Latent Heat And CO2 At The WLEF-TV Tower Using SiB2.5, Glob. Chang. Biol., 9(9), 1262-1277, 2003.

Baldocchi, D. D., Law, B. E., and Anthoni, P. M.: On Measuring And Modeling Energy Fluxes Above The Floor Of A Homogeneous And Heterogeneous Conifer Forest, Agric. For. Meteorol., 102(2-3), 187-206, 2000.

Baldocchi, D., Falge, E., Gu, L., Olson, R., Hollinger, D., Running, S., Anthoni, P., Bernhofer, C., Davis, K., Evans, R., Fuentes, J., Goldstein, A., Katul, G., Law, B., Lee, X., Malhi, Y., Meyers, T., Munger, W., Oechel, W., Paw, K. T., Pilegaard, K., Schmid, H. P., Valentini, R., Verma, S., Vesala, T., Wilson, K. and Wofsy, S.: FLUXNET: A New Tool to Study the Temporal and Spatial Variability of Ecosystem-Scale Carbon Dioxide, Water Vapor, and Energy Flux Densities, Bull. Am. Meteorol. Soc., 82(11), 2415-2434, doi:10.1175/1520-0477(2001)082<2415:FANTTS>2.3.CO;2, 2001.

Baldocchi, D. D., Xu, L., and Kiang, N.: How Plant Functional-Type, Weather, Seasonal Drought, And Soil Physical Properties Alter Water And Energy Fluxes Of An Oak-Grass Savanna And An Annual Grassland, Agric. For. Meteorol., 123(1-2), $13-39,2004$. Baldocchi, D. and Sturtevant, C.: Does day and night sampling reduce spurious correlation between canopy photosynthesis and ecosystem respiration?, Agric. For. Meteorol., 207(), 117-126, 2015.

Baldocchi, D., Penuelas, J.: The Physics And Ecology Of Mining Carbon Dioxide From The Atmosphere By Ecosystems, Glob. Chang. Biol., 256-257(2), 179-195, 2018.

Barcza, Z., Kern, A., Haszpra, L. and Kljun, N.: Spatial representativeness of tall tower eddy covariance measurements using 
remote sensing and footprint analysis, Agric. For. Meteorol., 149(5), 795-807, doi:10.1016/j.agrformet.2008.10.021, 2009. Barford, C. C., Wofsy, S. C., Goulden, M. L., Munger, J. W., Pyle, E. H., Urbanski, S. P., Hutyra, L., Saleska, S. R., Fitzjarrald, D., and Moore, K.: Factors Controlling Long- And Short-Term Sequestration Of Atmospheric CO2 In A Mid-Latitude Forest, Science, 294(5547), 1688-1691, 2001.

Barr, A. G., Griffis, T. J., Black, T. A., Lee, X., Staebler, R. M., Fuentes, J. D., Chen, Z., Morgenstern, K.: Comparing The Carbon Budgets Of Boreal And Temperate Deciduous Forest Stands, Canadian Journal Of Forest Research, 32(5), 813-822, 2002. Barr, J. G., Engel, V., Fuentes, J. D., Fuller, D. O., Kwon, H.: Modeling Light Use Efficiency In A Subtropical Mangrove Forest Equipped With Co2 Eddy Covariance, Biogeosciences, 10(3), 2145-2158, 2013.

Barron-Gafford, G. A., Scott, R. L., Jenerette, G. D., Hamerlynck, E. P., Huxman, T. E. (2013) Landscape And Environmental Controls Over Leaf And Ecosystem Carbon Dioxide Fluxes Under Woody Plant Expansion, Journal Of Ecology, 101(6), 1471-1483 Belshe, E. F., Schuur, E. A., Bolker, B. M., and Bracho, R.: Incorporating Spatial Heterogeneity Created By Permafrost Thaw Into A Landscape Carbon Estimate, J. Geophys. Res. Atmos.: Biogeosciences, 117(G1), 2012.

Belelli Marchesini, L., Papale, D., Reichstein, M., Vuichard, N., Tchebakova, N. and Valentini, R.: Carbon balance assessment of a natural steppe of southern Siberia by multiple constraint approach, Biogeosciences, 4(4), 581-595, doi:10.5194/bg-4-581-2007, 2007.

Bell, T. W., Menzer, O., Troyo-Diéquez, E., Oechel, W. C.: Carbon Dioxide Exchange Over Multiple Temporal Scales In An Arid Shrub Ecosystem Near La Paz, Baja California Sur, Mexico, Glob. Chang. Biol., 18(8), 2570-2582, 2012.

Beringer, J.: Adelaide River OzFlux tower site OzFlux: Australian and New Zealand Flux Research and Monitoring hdl: 102.100.100/14228, 2013a.

Beringer, J.: Dry River OzFlux tower site OzFlux, Australian and New Zealand Flux Research and Monitoring hdl: 102.100.100/14229, 2013b.

Beringer, J.: Fogg Dam OzFlux tower site OzFlux, Australian and New Zealand Flux Research and Monitoring hdl: 102.100.100/14233, 2013c.

Beringer, J.: Sturt Plains OzFlux tower site OzFlux, Australian and New Zealand Flux Research and Monitoring hdl: 102.100.100/14230, 2013d.

Beringer, J.: Yanco JAXA OzFlux tower site OzFlux, Australian and New Zealand Flux Research and Monitoring hdl: 102.100.100/14235, 2013e.

Beringer, J.: Wallaby Creek OzFlux tower site OzFlux, Australian and New Zealand Flux Research and Monitoring hdl: 102.100.100/14231, 2013f.

Beringer, J.: Red Dirt Melon Farm OzFlux tower site OzFlux: Australian and New Zealand Flux Research and Monitoring hdl: 102.100.100/14245, 2014a.

Beringer, J., :Riggs Creek OzFlux tower site OzFlux, Australian and New Zealand Flux Research and Monitoring hdl: 102.100.100/14246, 2014b.

Beringer, J.: Whroo OzFlux site OzFlux, Australian and New Zealand Flux Research and Monitoring hdl: 102.100.100/52559, 2017.

Biederman, J. A., Scott, R. L., Goulden, M. L., Vargas, R., Litvak, M. E., Kolb, T. E., Yepez, E. A., Oechel, W. C., Blanken, P. D., Bell, T. W., Garatuza-Payan, J., Maurer, G. E., Dore, S., and Burns, S. P.: Terrestrial Carbon Balance In A Drier World: The Effects Of Water Availability In Southwestern North America, Glob. Chang. Biol., 22(5), 1867-1879, 2016.

Billesbach, D. and Arkebauer, T. J. : AmeriFlux US-SdH Nebraska SandHills Dry Valley, Dataset, doi:10.17190/AMF/1246136, 2004.

Bodesheim, J.: BACl v1, Upscaled diurnal cycles of carbon and energy fluxes. Max Planck Institute for Biogeochemistry, Jena, (accessed on 3 October 2019), https://doi.org/10.17871/BACI.224, 2017.

Burba, G. G. and Verma, S. B.: Prairie Growth, PAR Albedo And Seasonal Distribution Of Energy Fluxes, Agric. For. Meteorol., 107(3), 227-240, 2001.

Burton, A. J. and Pregitzer, K. S.: Measurement Carbon Dioxide Concentration Does Not Affect Root Respiration Of Nine Tree Species In The Field, Tree Physiology, 22(1), 67-72, 2002.

Calperum Tech; Calperum Chowilla OzFlux tower site OzFlux: Australian and New Zealand Flux Research and Monitoring hdl: 102.100.100/14236, 2013.

Campbell, J. L., Sun, O. J., and Law, B. E.: Disturbance And Net Ecosystem Production Across Three Climatically Distinct Forest Landscapes, Global Biogeochem. Cycles, 18(4), 2004.

Castro, M. S., Gholz, H. L., Clark, K. L., Steudler, P. A.: Effects Of Forest Harvesting On Soil Methane Fluxes In Florida Slash Pine Plantations, Canadian Journal Of Forest Research, 30(10), 1534-1542, 2000.

Cescatti, A. and Zorer, R.: Structural acclimation and radiation regime of silver fir (Abies alba Mill.) shoots along a light gradient, Plant, Cell Environ., 26(3), 429-442, doi:10.1046/j.1365-3040.2003.00974.x, 2003. 
Chen, J. M., Govind, A., Sonnentag, O., Zhang, Y., Barr, and A., Amiro, B.: Leaf Area Index Measurements At Fluxnet-Canada Forest Sites, Agric. For. Meteorol., 140(1-4), 257-268, 2006. Chen, X.: Surface energy balance based global land evapotranspiration (SEBS) Daily ET dataset: (accessed on 9 April 2019), http://en.tpedatabase.cn/portal/MetaDatalnfo.jsp?MetaDatald=249454, 2017. Chi, J., Maureira, F., Waldo, S., Pressley, S. N., Stöckle, C. O., O'Keeffe, P. T., Pan, W. L., Brooks, E. S., Huggins, and D. R., Lamb, B. K.: Carbon And Water Budgets In Multiple Wheat-Based Cropping Systems In The Inland Pacific Northwest Us: Comparison Of Cropsyst Simulations With Eddy Covariance Measurements, Frontiers In Ecology And Evolution, 5, 25-36, 2017 a. Chi, J., Waldo, S., Pressley, S. N., Russell, E. S., O'Keeffe, P. T., Pan, W. L., Huggins, D. R., Stöckle, C. O., Brooks, E. S., and Lamb, B. K.: Effects Of Climatic Conditions And Management Practices On Agricultural Carbon And Water Budgets In The Inland Pacific Northwest Usa, J. Geophys. Res. Atmos.: Biogeosciences, 122(12), 3142-3160, 2017b.

Chu, H., Baldocchi, D. D., Poindexter, C., Abraha, M., Desai, A. R., Bohrer, G., Arain, M. A., Griffis, T., Blanken, P. D., O'Halloran, T. L., Thomas, R. Q., Zhang, Q., Burns, S. P., Frank, J. M., Christian, D., Brown, S., Black, T. A., Gough, C. M., Law, B. E., Lee, X., Chen, J., Reed, D. E., Massman, W. J., Clark, K., Hatfield, J., Prueger, J., Bracho, R., Baker, J. M., and Martin, T. A.: Temporal Dynamics Of Aerodynamic Canopy Height Derived From Eddy Covariance Momentum Flux Data Across North American Flux Networks, Geophysical Research Letters, 45(5), 9275-9287, 2018.

Cleverly, J.: Ti Tree East OzFlux Site OzFlux: Australian and New Zealand Flux Research and Monitoring hdl: 102.100.100/14225, 2013.

Cleverly, J., Boulain, N., Villalobos-Vega, R., Grant, N., Faux, R., Wood, C., Cook, P. G., Yu, Q., Leigh, A., and Eamus, D.: Dynamics of component carbon fluxes in a semi-arid Acacia wood- land, central Australia, J. Geophys. Res.-Biogeo., 118, 11681185, 2013.

Conte, M. H., Weber, J. C., Carlson, P. J., Flanagan, L. B.: Molecular And Carbon Isotopic Composition Of Leaf Wax In Vegetation And Aerosols In A Northern Prairie Ecosystem, Oecologia, 135(1), 67-77, 2003.

Copernicus Climate Change Service (C3S): C3S ERA5-Land reanalysis. Copernicus Climate Change Service, (accessed on 11 October 2019), https://cds.climate.copernicus.eu/cdsapp\#!/home, 2019.

Ershadi, A., McCabe, M. F., Evans, J. P., Chaney, N. W. and Wood, E. F.: Multi-site evaluation of terrestrial evaporation models using FLUXNET data, Agric. For. Meteorol., 187, 46-61, doi:10.1016/j.agrformet.2013.11.008, 2014.

Eugster, W., Rouse, W. R., Pielke Sr, R. A., Mcfadden, J. P., Baldocchi, D. D., Kittel, T. G. F., Chapin, F. S., Liston, G. E., Vidale, P. L., Vaganov, E. and Chambers, S.: Land-atmosphere energy exchange in Arctic tundra and boreal forest: available data and feedbacks to climate, Glob. Chang. Biol., 6(S1), 84-115, doi:10.1046/j.1365-2486.2000.06015.x, 2000.

Euskirchen, E. S., Bret-Harte, M. S., Shaver, G. R., Edgar, C. W., and Romanovsky, V. E.: Long-Term Release Of Carbon Dioxide From Arctic Tundra Ecosystems In Alaska, Ecosystems, 20(5), 960-974, 2017.

Ewenz, C.: Loxton OzFlux tower site OzFlux: Australian and New Zealand Flux Research and Monitoring hdl: 102.100.100/20838, 2015.

Galvagno, M., Wohlfahrt, G., Cremonese, E., Rossini, M., Colombo, R., Filippa, G., Julitta, T., Manca, G., Siniscalco, C., Morra di Cella, U. and Migliavacca, M.: Phenology and carbon dioxide source/sink strength of a subalpine grassland in response to an exceptionally short snow season, Environ. Res. Lett., 8, 025008, doi:10.1088/1748-9326/8/2/025008, 2013.

Gash, J. H. C. and Dolman, A. J.: Sonic anemometer (co)sine response and flux measurement I. The potential for (co)sine error to affect sonic anemometer-based flux measurements, Agric. For. Meteorol., 119, 195-207, doi:10.1016/S0168-1923(03)00137-0, 2003.

Gilmanov, T. G., Soussana, J. F., Aires, L., Allard, V., Ammann, C., Balzarolo, M., Barcza, Z., Bernhofer, C., Campbell, C. L., Cernusca, A., Cescatti, A., Clifton-Brown, J., Dirks, B. O. M., Dore, S., Eugster, W., Fuhrer, J., Gimeno, C., Gruenwald, T., Haszpra, L., Hensen, A., Ibrom, A., Jacobs, A. F. G., Jones, M. B., Lanigan, G., Laurila, T., Lohila, A., G.Manca, Marcolla, B., Nagy, Z., Pilegaard, K., Pinter, K., Pio, C., Raschi, A., Rogiers, N., Sanz, M. J., Stefani, P., Sutton, M., Tuba, Z., Valentini, R., Williams, M. L. and Wohlfahrt, G.: Partitioning European grassland net ecosystem $\mathrm{CO} 2$ exchange into gross primary productivity and ecosystem respiration using light response function analysis, Agric. Ecosyst. Environ., 121(1-2), 93-120, doi:10.1016/j.agee.2006.12.008, 2007.

Gilmanov, T. G., Aires, L., Barcza, Z., Baron, V. S., Belelli, L., Beringer, J., Billesbach, D., Bonal, D., Bradford, J., Ceschia, E., Cook, D., Corradi, C., Frank, A., Gianelle, D., Gimeno, C., Gruenwald, T., Guo, H., Hanan, N., Haszpra, L., Heilman, J., Jacobs, A., Jones, M. B., Johnson, D. A., Kiely, G., Li, S., Magliulo, V., Moors, E., Nagy, Z., Nasyrov, M., Owensby, C., Pinter, K., Pio, C., Reichstein, M., Sanz, M. J., Scott, R., Soussana, J. F., Stoy, P. C., Svejcar, T., Tuba, Z. and Zhou, G.: Productivity, Respiration, and LightResponse Parameters of World Grassland and Agroecosystems Derived From Flux-Tower Measurements, Rangel. Ecol. Manag., 63(1), 16-39, doi:10.2111/REM-D-09-00072.1, 2010.

Hilton, T. W., Davis, K. J. and Keller, K.: Evaluating terrestrial CO2 flux diagnoses and uncertainties from a simple land surface model and its residuals, Biogeosciences, 11, 217-235, doi:10.5194/bg-11-217-2014, 2014.

Hirano, T., Segah, H., Harada, T., Limin, S., June, T., Hirata, R. and Osaki, M.: Carbon dioxide balance of a tropical peat swamp forest in Kalimantan, Indonesia, Glob. Chang. Biol., 13(2), 412-425, doi:10.1111/j.1365-2486.2006.01301.x, 2007. 
Hirata, R., Saigusa, N., Yamamoto, S., Ohtani, Y., Ide, R., Asanuma, J., Gamo, M., Hirano, T., Kondo, H., Kosugi, Y., Li, S. G., Nakai, Y., Takagi, K., Tani, M. and Wang, H.: Spatial distribution of carbon balance in forest ecosystems across East Asia, Agric. For. Meteorol., 148(5), 761-775, doi:10.1016/j.agrformet.2007.11.016, 2008.

Ikawa, H., Nakai, T., Busey, R., Kim, Y., Kobayashi, H., Nagai, S., Ueyama, M., Saito, K., Nagano, H., Suzuki, R. and Hinzman, L.: Understory CO2, sensible heat, and latent heat fluxes in a black spruce forest in interior Alaska, Agric. For. Meteorol., 214215, 80-90, 2015.

Irvine, J., Law, B. E. and Hibbard, K. A.: Postfire carbon pools and fluxes in semiarid ponderosa pine in Central Oregon, Glob. Chang. Biol., 13(8), 1748-1760, doi:10.1111/j.1365-2486.2007.01368.x, 2007.

King, M. D., Platnick, S., Moeller, C. C., Revercomb, H. E. and Chu, D. A.: Remote sensing of smoke, land, and clouds from the NASA ER-2 during SAFARI 2000, J. Geophys. Res. Atmos., 108(D13), doi:10.1029/2002JD003207, 2003.

Isaac P.: Daly Regrowth OzFlux tower site_old_20131128 OzFlux: Australian and New Zealand Flux Research and Monitoring hdl: 102.100.100/14215, 2010.

Jamali, H., Livesley, S. J., Dawes, T. Z., Cook, G. D., Hutley, L. B. and Arndt, S. K.: Diurnal and seasonal variations in CH4 flux from termite mounds in tropical savannas of the Northern Territory, Australia, Agric. For. Meteorol., 151(11), 1471-1479, doi:10.1016/j.agrformet.2010.06.009, 2011.

Keppel-Aleks, G., Wennberg, P. O., Washenfelder, R. A., Wunch, D., Schneider, T., Toon, G. C., Andres, R. J., Blavier, J.-F., Connor, B., Davis, K. J., Desai, A. R., Messerschmidt, J., Notholt, J., Roehl, C. M., Sherlock, V., Stephens, B. B., Vay, S. A., and Wofsy, S. C.: The imprint of surface fluxes and transport on variations in total column carbon dioxide, Biogeosciences, 9, 875891, doi:10.5194/bg-9-875-2012, 2012.

Jung, M. et al.: FLUXCOM Global Land Energy Fluxes. Max Planck Institute for Biogeochemistry, Jena, (accessed on 2 October 2019), https://doi.org/10.17871/FLUXCOM_EnergyFluxes_v1 (2018)

Lafleur, P. M., Roulet, N. T., Bubier, J. L., Frolking, S. and Moore, T. R.: Interannual variability in the peatland-atmosphere carbon dioxide exchange at an ombrotrophic bog, Global Biogeochem. Cycles, 17(2), 1036, doi:10.1029/2002GB001983, 2003. Laubach, J.: Beacon Farm OzFlux: Australian and New Zealand Flux Research and Monitoring hdl: 102.100.100/26730, 2016. Li, X., Liang, S., Yu, G., Yuan, W., Cheng, X., Xia, J., Zhao, T., Feng, J., Ma, Z., Ma, M., Liu, S., Chen, J., Shao, C., Li, S., Zhang, X., Zhang, Z., Chen, S., Ohta, T., Varlagin, A., Miyata, A., Takagi, K., Saiqusa, N. and Kato, T.: Estimation of gross primary production over the terrestrial ecosystems in China, Ecol. Modell., 261-262, 80-92, doi:10.1016/j.ecolmodel.2013.03.024, 2013. Liddell, M.: Cape Tribulation OzFlux tower site OzFlux: Australian and New Zealand Flux Research and Monitoring hdl: 102.100.100/14242, 2013a Liddell, M.: Robson Creek OzFlux tower site OzFlux: Australian and New Zealand Flux Research and Monitoring hdl: 102.100.100/14243, 2013b.

Loubet, B., Laville, P., Lehuger, S., Larmanou, E., Fléchard, C., Mascher, N., Genermont, S., Roche, R., Ferrara, R. M., Stella, P., Personne, E., Durand, B., Decuq, C., Flura, D., Masson, S., Fanucci, O., Rampon, J.-N., Siemens, J., Kindler, R., Gabrielle, B., Schrumpf, M. and Cellier, P.: Carbon, nitrogen and Greenhouse gases budgets over a four years crop rotation in northern France, Plant Soil, 343(1-2), 109-137, doi:10.1007/s11104-011-0751-9, 2011. Macfarlane, C.: Great Western Woodlands OzFlux: Australian and New Zealand Flux Research and Monitoring hdl: 102.100.100/14226, 2013.

McCaughey, J. H., Pejam, M. R., Arain, M. A., and Cameron, D. A.: Carbon dioxide and energy fluxes from a boreal mixedwood forest ecosystem in Ontario Canada, Agr. Forest Meteorol., 140, 79-96, 2006.

Mu, Q.: Mod16a2_monthly.Merra_gmao_1kmalb. (accessed on 1 October 2019), http://files.ntsg.umt.edu/data/NTSG_Products/MOD16/MOD16A2_MONTHLY.MERRA_GMAO_1kmALB/, 2015. Noormets, A., Chen, J. and Crow, T. R.: Age-Dependent Changes in Ecosystem Carbon Fluxes in Managed Forests in Northern Wisconsin, USA, Ecosystems, 10(2), 187-203, doi:10.1007/s10021-007-9018-y, 2007. ORNL DAAC: Home | fluxnetweb.ornl.gov, [online] Available from: https://fluxnet.ornl.gov/ (Accessed 1 July 2019 ), 2015. Pendall E.: Cumberland Plain OzFlux Tower Site OzFlux: Australian and New Zealand Flux Research and Monitoring hdl: 102.100.100/25164, 2015.

Saleska, S.R., H.R. da Rocha, A.R. Huete, A.D. Nobre, P. Artaxo, and Y.E. Shimabukuro: . LBA-ECO CD-32 Flux Tower Network Data Compilation, Brazilian Amazon: 1999-2006. Data set. Available on-line [http://daac.ornl.gov] from Oak Ridge National Laboratory Distributed Active Archive Center, Oak Ridge, Tennessee, USA, doi:10.3334/ORNLDAAC/1174, 2013. Reichstein, M., Rey, A., Freibauer, A., Tenhunen, J., Valentini, R., Banza, J., Casals, P., Cheng, Y., Grünzweig, J. M., Irvine, J., Joffre, R., Law, B. E., Loustau, D., Miglietta, F., Oechel, W., Ourcival, J.-M., Pereira, J. S., Peressotti, A., Ponti, F., Qi, Y., Rambal, S., Rayment, M., Romanya, J., Rossi, F., Tedeschi, V., Tirone, G., Xu, M. and Yakir, D.: Modeling temporal and large-scale spatial variability of soil respiration from soil water availability, temperature and vegetation productivity indices, Global Biogeochem. Cycles, 17(4), doi:10.1029/2003GB002035, 2003.

Reichstein, M., Falge, E., Baldocchi, D., Papale, D., Aubinet, M., Berbigier, P., Bernhofer, C., Buchmann, N., Gilmanov, T., Granier, A., Grunwald, T., Havrankova, K., Ilvesniemi, H., Janous, D., Knohl, A., Laurila, T., Lohila, A., Loustau, D., Matteucci, G., Meyers, T., Miglietta, F., Ourcival, J.-M., Pumpanen, J., Rambal, S., Rotenberg, E., Sanz, M., Tenhunen, J., Seufert, G., Vaccari, F., Vesala, 
T., Yakir, D. and Valentini, R.: On the separation of net ecosystem exchange into assimilation and ecosystem respiration: review and improved algorithm, Glob. Chang. Biol., 11(9), 1424-1439, doi:10.1111/j.1365-2486.2005.001002.x, 2005. Revill, A., Sus, O., Barrett, B. and Williams, M.: Carbon cycling of European croplands: A framework for the assimilation of optical and microwave Earth observation data, Remote Sens. Environ., 137, 84-93, doi:10.1016/j.rse.2013.06.002, 2013. Schroder, I.: Arcturus Emerald OzFlux tower site OzFlux: Australian and New Zealand Flux Research and Monitoring hdl: 102.100.100/14249, 2014.

Silberstein, R: Gingin OzFlux, Australian and New Zealand Flux Research and Monitoring hdl: 102.100.100/22677, 2015. Soegaard, H. and Nordstroem, C.: Carbon dioxide exchange in a high-arctic fen estimated by eddy covariance measurements and modelling, Glob. Chang. Biol., 5(5), 547-562, doi:10.1111/j.1365-2486.1999.00250.x, 1999.

Stoy, P. C., Mauder, M., Foken, T., Marcolla, B., Boegh, E., Ibrom, A., Arain, M. A., Arneth, A., Aurela, M., Bernhofer, C., Cescatti, A., Dellwik, E., Duce, P., Gianelle, D., van Gorsel, E., Kiely, G., Knohl, A., Margolis, H., Mccaughey, H., Merbold, L., Montagnani, L., Papale, D., Reichstein, M., Saunders, M., Serrano-Ortiz, P., Sottocornola, M., Spano, D., Vaccari, F. and Varlagin, A.: A datadriven analysis of energy balance closure across FLUXNET research sites: The role of landscape scale heterogeneity, Agric. For. Meteorol., 171-172, 137-152, doi:10.1016/j.agrformet.2012.11.004, 2013.

Stefan A.: Wombat State Forest OzFlux-tower site OzFlux: Australian and New Zealand Flux Research and Monitoring hdl: 102.100.100/14237, 2013.

Sulkava, M., Luyssaert, S., Zaehle, S. and Papale, D.: Assessing and improving the representativeness of monitoring networks: The European flux tower network example, J. Geophys. Res., 116(G3), G00J04, doi:10.1029/2010JG001562, 2011. Wei, S., Yi, C., Hendrey, G., Eaton, T., Rustic, G., Wang, S., Liu, H., Krakauer, N. Y., Wang, W., Desai, A. R., Montagnani, L., Tha Paw U, K., Falk, M., Black, A., Bernhofer, C., Grünwald, T., Laurila, T., Cescatti, A., Moors, E., Bracho, R. and Valentini, R.: Databased perfect-deficit approach to understanding climate extremes and forest carbon assimilation capacity, Environ. Res. Lett., 9, 065002, doi:10.1088/1748-9326/9/6/065002, 2014.

Wood, E.: Princeton University SRB/GEWEX evapotranspiration (Penman-Monteith) L4 3 hour 0.5 degree x 0.5 degree V1, Greenbelt, MD USA, Goddard Earth Sciences Data and Information Services Center (GES DISC), (accessed on 1 October 2019), 10.5067/MEASURES/WATERCYCLE/DATA314, 2017

Woodgate, W.: Tumbarumba OzFlux tower site OzFlux: Australian and New Zealand Flux Research and Monitoring hdl: 102.100.100/14241, 2013.

Zhang, Y., Pena A. J., McVicar, T. Chiew, F.; Vaze, J., Zheng, H., Wang, Y.: Monthly global observation-driven Penman-MonteithLeuning (PML) evapotranspiration and components. v2. CSIRO. Data Collection. (accessed on 9 April 2019), https://doi.org/10.4225/08/5719A5C48DB85, 2016.

Zhang, Ke: PLSH Monthly Global 8kmResolution: (accessed on 30 September 2019), http://files.ntsg.umt.edu/data/ET_global_monthly/Global_8kmResolution/, 2017. 